\title{
ORIGINALISM AND STRUCTURAL ARGUMENT
}

\begin{abstract}
The "new originalism" is all about the text of the Constitution. Originalists insist that the whole point of originalism is to respect and follow the original meaning of the text, and that originalism derives its legitimacy from its unwavering focus on the text alone as the sole basis of higher law. And yet, many leading Supreme Court decisions in matters of great importance to conservatives - in opinions authored and joined by originalist judges, and often praised by originalist scholars - are seemingly not grounded in the constitutional text at all. They rest instead on abstract structural argument: on freestanding principles of federalism and separation of powers in lieu of the original meaning of any particular provision of the Constitution. This Essay demonstrates and examines the underexplored tension between original meaning textualism and structural argument.
\end{abstract}

AUTHOR - John Theodore Fey Research Professor of Law, The George Washington University Law School.

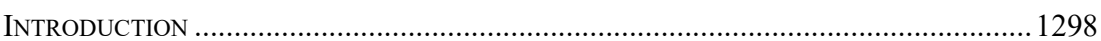

I. The Centrality of the TeXt to the New OriginAlism …...............................1303

II. The Prevalence of Structural Reasoning in the Conservative

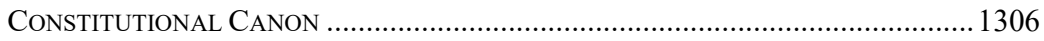

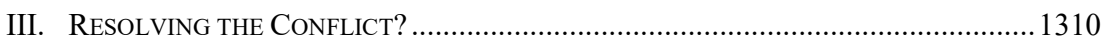

A. Denying the Conflict: Structuralism as Holistic Textualism ......................1310

B. Averting the Conflict: Rejecting Structural Reasoning............................. 1318

C. Eluding the Conflict: Textual Hooks................................................... 1319

D. Tolerating the Conflict: Acknowledging a Large Construction Zone ....... 1322

E. Transcending the Conflict: Accepting an Unwritten Constitution ............. 1325

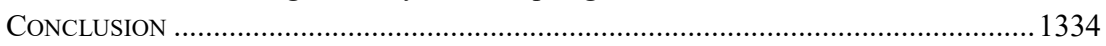




\section{INTRODUCTION}

Today's originalism, often referred to as the "new originalism," is all about the text of the Constitution. ${ }^{1}$ Originalists insist that they are "looking for ... the original meaning of the text." 2 This is not a peripheral or accidental feature of modern originalism. It is the very essence and centerpiece of the theory.

Recently, in defending and demanding originalism before the Senate Judiciary Committee in Justice Neil Gorsuch's confirmation hearings, Professor Lawrence Solum, one of the leading figures in the academic originalist movement, insisted that the "whole point of originalism is to respect the text." " "The core of originalism," Professor Solum explained, "is a very simple idea. In constitutional cases, the United States Supreme Court should consider itself bound by the original public meaning of the constitutional text." ${ }^{4}$ That is to say, "[o]riginalism is about the constitutional text. .. What matters for originalists is what the constitutional text says." 5

This fundamental commitment to the text is, originalists insist, essential to the rule of law. Professor Solum continues, "The truth is that if the constitutional text does not bind the Supreme Court, then the Justices are the equivalent of a superlegislature or a perpetual constitutional convention. A committee of nine unelected judges has the power to reshape our Constitution as they see fit." ${ }^{\circ}$ And it is likewise essential for democratic legitimacy: "Each and every provision of the United States Constitution has been ratified by a supermajoritarian process" which confers democratic legitimacy. ${ }^{7}$ Professor Solum concludes that,

[i]f we must choose between originalism and constitutional text that has been ratified by the representatives of "We the People" and a living constitutionalist

\footnotetext{
1 See Lawrence B. Solum, Originalism and the Unwritten Constitution, 2013 U. ILL. L. REV. 1935, 1936 ("The predominate form of contemporary originalism is textualist; let's call this form of originalism "public meaning originalism."”); $i d$. at 1943 (noting that "original public meaning originalism" is sometimes called "the new originalism").

2 Antonin Scalia, Common-Law Courts in a Civil-Law System: The Role of United States Federal Courts in Interpreting the Constitution and Laws, in A MATTER OF INTERPRETATION: FEDERAL COURTS AND THE LAW 3, 45 (Amy Gutmann ed., 1997).

${ }^{3}$ Hearings on the Nomination of the Honorable Neil M. Gorsuch to Be an Associate Justice of the Supreme Court of the United States Before the S. Comm. on the Judiciary, 115th Cong. 9 (2017) (statement of Lawrence B. Solum, Professor, Georgetown University Law Center), https://www.judiciary.senate.gov/imo/media/doc/03-23-17\%20Solum\%20Testimony.pdf [https://perma.cc/UP9D-CKUT].

${ }^{4} I d$. at 1.

5 Id. at 2 .

${ }^{6}$ Id. at 7.

${ }^{7}$ Id.
} 
constitution that is ratified by majority vote of a committee of nine, there is no doubt ... about which constitution is the more democratic. ${ }^{8}$

The text, then, is the be-all and end-all. Indeed, so wedded is the new originalism to the constitutional text that some leading new originalists have taken to calling their theory "original public meaning textualism."

And yet, curiously, many leading Supreme Court decisions in matters of great importance to conservatives - in opinions authored and joined by originalist judges, and often praised by originalist scholars - are seemingly not grounded in the constitutional text at all. ${ }^{10}$ As Professor John Manning has noted, "The Rehnquist and Roberts Courts have repeatedly invalidated statutory programs, but not because those programs violated some particular constitutional provision.... Rather, its 'new structuralism' rests on freestanding principles of federalism and separation of powers." 11 In these cases, "the Court's judgment is not ultimately tied to the understood meaning of any particular constitutional text." 12

Take, for instance, Printz v. United States, ${ }^{13}$ in which the Court found in the Constitution a significant limit on federal power despite its open admission that there was "no constitutional text speaking to th[e] precise question." ${ }^{14}$ Or Alden v. Maine,${ }^{15}$ which immunized states from lawsuits on the basis of a principle that is not set out in any constitutional provision but rather, we are told, "inheres in the system of federalism established by the Constitution" - $a$ "structural basis of sovereign immunity implicit in the constitutional design." 16

The decisions in these cases are grounded in abstract notions of constitutional structure, rather than the original meaning of the constitutional text. ${ }^{17}$ In the so-called conservative revolution in federalism and separation

\footnotetext{
${ }^{8} I d$. at 8

9 Vasan Kesavan \& Michael Stokes Paulsen, The Interpretive Force of the Constitution's Secret Drafting History, 91 GEO. L.J. 1113, 1132-33 (2003).

${ }^{10}$ See Thomas B. Colby, The Sacrifice of the New Originalism, 99 GEO. L.J. 713, 755 n.253 (2011) ("Originalists ... often endorse structural arguments that are not clearly grounded in constitutional text.").

11 John F. Manning, Foreword: The Means of Constitutional Power, 128 HARV. L. REV. 1, 4 (2014) [hereinafter Manning, Foreword] (internal citations omitted); see also John F. Manning, Federalism and the Generality Problem in Constitutional Interpretation, 122 HARV. L. REV. 2003, 2004 (2009) [hereinafter Manning, Generality] ("In recent years, the Supreme Court has embraced a freestanding federalism that is not tied to any particular clause of the Constitution.").

12 Manning, Foreword, supra note 11, at 31.

13521 U.S. 898 (1997).

${ }^{14} \mathrm{Id}$. at 905 .

15527 U.S. 706 (1999).

16 Id. at $730-31$.

17 See Manning, Foreword, supra note 11, at 32.
} 
of powers, ${ }^{18}$ it is mostly structural arguments - not textual ones - that have carried the day. ${ }^{19}$

Structural argument is, in Professor Michael Dorf's words, "a method of constitutional interpretation in which the reader draws inferences" not from the text of the Constitution but rather "from the relationship among the structures of government-such as Congress, the Presidency, and the states." 20

But wait! How can public meaning originalists who believe that "originalists ought to begin and end all analysis with the original public meaning of constitutional texts" ${ }^{21}$ and "give priority to the ... Constitution's text... because they believe that it and it alone is law"22 countenance constitutional decisions that are manifestly grounded in constitutional structure in lieu of the public meaning of the text?

Consider Justice Scalia, whom many originalists consider to be "original meaning textualism's patron saint." ${ }^{23}$ He generally insisted that "[n]o judge, in any court, applying what purports to be a principle of constitutional law that overrides the activities of the legislature or the executive, appeals to anything except the written Constitution." ${ }^{24}$ And yet he also proclaimed that "[s]tructure is everything." ${ }^{25} \mathrm{He}$ was the author of the Court's openly nontextualist opinion in Printz, and he proudly explained that, in that case and others, he had found laws unconstitutional for violating the "two main features" of "constitutional structure": "(1) separation and

18 See, e.g., Linda Greenhouse, Ideas and Trends: Divided They Stand; The High Court and the Triumph of Discord, N.Y. TimES (July 15, 2001), https://www.nytimes.com/2001/07/15/weekinreview /ideas-trends-divided-they-stand-the-high-court-and-the-triumph-of-discord.html

[https://perma.cc/Q7N9-GRT2] ("There is a revolution in progress at the court, with Chief Justice William H. Rehnquist and Justices [Antonin] Scalia, Sandra Day O'Connor, Anthony M. Kennedy and Clarence Thomas challenging long-settled doctrines governing state-federal relations, the separation of powers, property rights and religion.").

19 See infra Part II.

${ }^{20}$ Michael C. Dorf, Interpretive Holism and the Structural Method, or How Charles Black Might Have Thought About Campaign Finance Reform and Congressional Timidity, 92 GEO. L.J. 833, 833 (2004); see also Philip BobBitt, Constitutional Fate: Theory of the Constitution 74 (1982) ("Structural arguments are inferences from the existence of constitutional structures and the relationships which the Constitution ordains among these structures.").

${ }^{21}$ Steven G. Calabresi \& Julia T. Rickert, Originalism and Sex Discrimination, 90 TEX. L. REv. 1, 4 (2011).

${ }^{22}$ Steven G. Calabresi \& Saikrishna B. Prakash, The President's Power to Execute the Laws, 104 YALE L.J. 541, 552 (1994).

${ }^{23}$ Kesavan \& Paulsen, supra note 9, at 1139.

24 Antonin Scalia, Is There an Unwritten Constitution?, 12 HARV. J.L. \& PUB. POL'Y 1, 1 (1989)

25 Antonin Scalia, Foreword: The Importance of Structure in Constitutional Interpretation, 83 Notre DAME L. REV. 1417, 1418 (2008). 
equilibrium of powers and (2) federalism." ${ }^{26}$ Recognizing that "the text of the Constitution often fails to address matters implicit in the constitutional structure," 27 Professor Brad Clark (an ardent originalist supporter of these decisions) explains, "Justice Scalia's goal in these cases [was] to uphold the original constitutional structure in order to respect the Founders' constitutional design and to protect individual liberty." 28

There is an obvious tension between original meaning textualism and structural argument, and it is one that has not been sufficiently explored in the originalist literature. There seems to be a general understanding, shared by originalists and nonoriginalists alike, that structural arguments - at least those that are grounded in the original understanding of the structure - are originalist in nature. ${ }^{29}$ And in some ways they surely are. There are some forms of originalism - those less obsessed with the constitutional text - that might fairly seem to welcome them. ${ }^{30}$

Those are not, however, the dominant strains of originalist thought today. Structural reasoning is much harder to square with an originalism that insists on fidelity to the original public meaning of the text. ${ }^{31}$ Cases grounded

26 Id. at $1418-20$.

27 Bradford R. Clark, The Constitutional Structure and the Jurisprudence of Justice Scalia, 47 ST. LOUIS U. L.J. 753, 762 (2003).

28 Id. at 754; see also William K. Kelley, Justice Scalia, the Nondelegation Doctrine, and Constitutional Argument, 92 Notre DAME L. REV. 2107, 2122 (2017) ("Justice Scalia was a big fan of structural argument in constitutional law. Indeed, some of his most famous opinions rely heavily on the structural principles of separation of powers and federalism.")

29 See, e.g., Clark, supra note 27, at 771 ("Justice Scalia's commitment to the original understanding of the Constitution naturally leads him to embrace both federalism and separation of powers. . . [I]t is entirely foreseeable that Justice Scalia — a self-described originalist-would seek to implement both features of the original constitutional structure."); James E. Fleming, Securing Deliberative Autonomy, 48 STAN. L. REV. 1, 5 (1995) (“[E]ven narrow originalists . . readily engage in structural reasoning concerning separation of powers, federalism, and a republican form of government."); Thomas B. McAffee, Originalism and Indeterminacy, 19 HARV. J.L. \& PUB. POL'Y 429, 432 n.15 (1996) (noting that "virtually all originalists recognize that originalism encompasses structural arguments"); Diarmuid F. O'Scannlain, The Role of the Federal Judge in the Constitutional Structure: An Originalist Perspective, 50 SAN DIEGo L. REV. 517, 518 (2013) ("[O]riginalism speaks not just of the meaning of the Constitution's textual provisions. It speaks also of the structure established by the Constitution, of the role that each branch plays in that structure, and of the respect that the federal branches owe to the states and to the people.”); Stephen E. Sachs, Originalism Without Text, 127 YALE L.J. 156, 166 (2017) (noting that these "are widely understood to be originalist arguments").

30 See infra Section III.E.

31 See, e.g., Michael B. Rappaport, Reconciling Textualism and Federalism: The Proper Textual Basis of the Supreme Court's Tenth and Eleventh Amendment Decisions, 93 Nw. U. L. REV. 819, 828 (1999) (discussing Justice Scalia's opinion in Printz that relied on "historical understanding and practice, ... the structure of the Constitution, and . . the jurisprudence of th[e] Court" because there was no Constitutional text on the question and arguing that "[f]rom a textualist perspective, this methodology is problematic"); Ernest A. Young, Alden v. Maine and the Jurisprudence of Structure, 41 WM. \& MARY L. REV. 1601, 1622 (2000) (noting "the Alden Court's departure from textualism-and any form of originalism consistent with textualism”). 
in structural reasoning "are a source of vague embarrassment for an originalism centered on specific constitutional phrases." 32 And yet few public meaning originalists have openly wrestled with the issue or sought to reconcile the structural cases with their methodological commitments.

One prominent originalist who has done so is Professor Michael Ramsey. His recent conclusion appears to amount to a confession that these cases are not consistent with an unadulterated public meaning strain of originalism. ${ }^{33}$ Rather, they are "evidence that Scalia's methodology was less strictly text-based than commonly supposed (and indeed perhaps less strictly text-based than he sometimes acknowledged in his theoretical discussions)." " ${ }_{34}$ Professor Ramsey explains that these decisions are nonetheless "originalist" in that "[t]hey are all based on structural assumptions and implications he derived from the founding era and the Constitution's original design. Thus they show, not that Scalia was an inconsistent originalist, but that he was a structuralist as well as a textualist in his originalism." 35

Some nonoriginalists have seized upon the inconsistency as proof that originalists are just political actors, committed more to conservative results than to theoretical rigor and consistency. ${ }^{36}$

Are they right? Is Professor Ramsey right? What is the relationship among text, structure, ${ }^{37}$ and originalism? This Essay does not purport to

32 Sachs, supra note 29, at 166; see also William Baude, Sovereign Immunity and the Constitutional Text, 103 VA. L. REV. 1,7 (2017) (noting that these doctrines pose "a difficulty for those who claim that it is the written document, not its penumbras and emanations, that supplies our constitutional law").

33 See Michael D. Ramsey, Beyond the Text: Justice Scalia's Originalism in Practice, 92 NOTRE DAME L. REV. 1945, 1946 (2017) (arguing that the "structural reasoning and background assumptions" in these cases have gone "substantially beyond the Constitution's words, sometimes in ways that may be surprising to originalist theorists and practitioners").

${ }^{34} I d$. at 1952.

35 Id.

36 See, e.g., Gene R. Nichol, Justice Scalia and the Printz Case: The Trials of an Occasional Originalist, 70 U. COLO. L. REV. 953, 969-71 (1999) (noting that Justice Scalia sometimes departed from his originalist ideas to invalidate acts of Congress "because he and his colleagues thought [they were] bad idea[s]"); Eric J. Segall, The Constitution According to Justices Scalia and Thomas: Alive and Kickin', 91 WASH. U. L. REV. 1663 (2014) (arguing that Justices Scalia and Thomas frequently used living constitutionalist principles to reach their conclusions); Eric Segall, Text and History Fed Soc Style, DoRF ON LAW (Nov. 20, 2017), http://www.dorfonlaw.org/2017/11/text-and-history-fed-soc-style.html [https://perma.cc/5UYL-6AUE] ("[M]y strong guess is that most of the people clapping wildly for textualist judges at the convention agree with the equal state sovereignty principle the Court espoused in Shelby County, the anti-commandeering principle of Printz v. United States, ... and the sovereign immunity principle applicable to suits against states by their own citizens that the Court concocted in Hans and reaffirmed in Seminole Tribe. None of those important constitutional limitations on governmental discretion can be found anywhere in the Constitution's text.").

37 The term "constitutional structure" has many meanings in constitutional law. It is often used to distinguish the provisions of the Constitution that establish the architecture of the American system of 
answer those questions definitively, but it hopes to shed some helpful light on them.

\section{The Centrality of the TeXt to THE New ORIGinAlisM}

In its early days, originalism was generally understood as a "jurisprudence of original intention" that focused on the original intent of the Framers. ${ }^{38}$ But originalism has evolved. ${ }^{39}$ As Justice Scalia, who led a "campaign to change the label from the Doctrine of Original Intent to the Doctrine of Original Meaning," 40 explained, originalists now seek "the original meaning of the text, not what the original draftsmen intended." 41

Today, "the foundation of originalist theory," one of its proponents explains, is that the "Constitution is a written document that was publicly adopted as law, and it therefore means what its words meant to the relevant public audience at the time of its adoption." 42 And it is those words that matter. The constitutional text is the heart of the new originalism. ${ }^{43}$ In its modern incarnation, "originalism is a species of textualism." ${ }^{44}$ It affords constitutional status only to those views of the Framing generation that were reflected in the ratified text. ${ }^{45}$

government from those that delineate the rights of the people. See, e.g., Ozan O. Varol, Structural Rights, 105 GEO. L.J. 1001, 1002-03 (2017) (explaining the "dichotomy between constitutional structure and constitutional rights"). This Essay uses the term in a different way-to refer to arguments about the content of constitutional law that are derived from the structural relationships between the institutions of government established or regulated by the Constitution. Those arguments can and often are used to answer questions of both governmental architecture and individual rights, though the Court's conservatives tend to apply them much more to questions of architecture. See infra Part II.

38 Edwin Meese III, Address Before the DC Chapter of the Federalist Society Lawyers Division (Nov. 15, 1985), in Original MEANing Jurisprudence: A SOURCEBOOK 91, 96 (1987) [hereinafter SOURCEBOOK]; see also RAOUL BERGER, GOVERNMENT BY JUDICIARY: THE TRANSFORMATION OF THE FOURTEENTH AMENDMENT 4 ( $2 \mathrm{~d}$ ed. 1997) (declaring that the "“original intention' of the Framers ... is binding on the Court").

39 This story has been oft told elsewhere, including Colby, supra note 10, at 716-36.

40 Antonin Scalia, Address Before the Attorney General's Conference on Economic Liberties in Washington, D.C. (June 14, 1986), in SOURCEBOOK, supra note 38, at 101, 106 (1987).

41 Scalia, supra note 2, at 38.

42 Nelson Lund, The Second Amendment, Heller, and Originalist Jurisprudence, 56 UCLA L. REV. 1343, 1346 (2009).

43 See, e.g., William Baude, Is Originalism Our Law?, 115 COLuM. L. REV. 2349, 2357 (2015) (“The Constitution's text is generally central to originalism."); Peter J. Smith \& Robert W. Tuttle, Biblical Literalism and Constitutional Originalism, 86 NOTRE DAME L. REV. 693, 721 (2011) (noting that a defining feature of "constitutional originalism is the centrality of the text to the interpretive enterprise").

${ }^{44}$ Stephen A. Siegel, The Federal Government's Power to Enact Color-Conscious Laws: An Originalist Inquiry, 92 Nw. U. L. REV. 477, 485 (1998).

45 See id. (noting that "[o]riginalism does not secure any norm unless there is some text intended to secure it that went through the adoption and ratification gauntlet"). 
This limited focus is the core of new originalist theory and essential to the mainstream originalist conception of the rule of law and the legitimacy of judicial review. ${ }^{46}$ As Professors Steven Calabresi and Saikrishna Prakash put it, "Originalists do not give priority to the plain dictionary meaning of the Constitution's text because they like grammar more than history. They give priority to it because they believe that it and it alone is law." ${ }^{47}$ On this view, once a judge deviates from the ratified text, she is making law, rather than following it.

The intentions or expectations that the Framers may have had about the effects of the Constitution are largely irrelevant. ${ }^{48}$ Public meaning originalists care only about the "meaning of the words of the Constitution to the society that adopted it - regardless of what the Framers might secretly have intended." ${ }^{49}$ In other words, "[t]he text is the law, and it is the text that must be observed." ${ }_{50}$

Indeed, public meaning originalists claim that their theory follows from the very nature of the Constitution as a written document ${ }^{51}$ that, by its own terms, declares itself to be the supreme law of the land. ${ }^{52}$ Professor Michael Paulsen colorfully elucidates:

The central feature of the document - the first thing one notices about it, if not a dolt or a mystic - is its written-ness. America's Constitution is a written constitution, not an unwritten one. And our written Constitution directs that it is "this Constitution"- a written document - that is supposed to be the supreme Law of the Land, not anything else. ${ }^{53}$

\footnotetext{
46 See Michael W. McConnell, Textualism and the Dead Hand of the Past, 66 GeO. WASH. L. REV. 1127,1136 (1998) ("When a judge goes beyond the meaning of the words that were enacted . . . the judge has no democratic warrant. The constitutional text is, therefore, the first and foremost consideration in judging."); Victoria Nourse, Reclaiming the Constitutional Text from Originalism: The Case of Executive Power, 106 CALIF. L. REV. 1, 7 (2018) (noting “originalism's most basic claim-that the text of the Constitution is the rule of law"); Smith \& Tuttle, supra note 43, at 712 (noting that "virtually all originalists stress the importance of text because the text encodes an authoritative set of instructions that embodies the sovereign will").

${ }^{47}$ Calabresi \& Prakash, supra note 22, at 552.

48 Except as evidence of the objective meaning of the text. See Colby, supra note 10, at 741.

49 Scalia, supra note 40, at 103.

50 Scalia, supra note 2, at 22.

51 See RANDy E. BARnett, Restoring the Lost CONSTItUtion: The PRESUmption OF LiBerty 100-09 (2004) (explaining that originalism is tied up with the writtenness of the Constitution); Smith \& Tuttle, supra note 43, at 711 ("To modern originalists, a corollary of the importance of the Constitution's writtenness is that the constitutional text must be central to constitutional interpretation.").

52 See Kesavan \& Paulsen, supra note 9, at 1127 (citing U.S. ConST. art. VI, cl. 2).

53 Michael Stokes Paulsen, How to Interpret the Constitution (and How Not To), 115 YALE L.J. 2037, 2049 (2006).
} 
From this essential characteristic, many originalists deduce that "the Constitution ... prescribes textualism as the sole, legitimate method for interpreting and applying the Constitution as authoritative, controlling law." 54

Originalism has a big tent, and there is a great deal of intermural disagreement among the originalist ranks. ${ }^{55}$ But virtually all originalistseven those on the less textual end of the scale-have tended to coalesce around Professor Solum's catholic definition that two ideas represent the "core" of contemporary originalism. First, the "Fixation Thesis" states that "the linguistic meaning of the constitutional text is fixed for each provision at the time that provision was framed and ratified." ${ }_{56}$ Second, the "Constraint Principle" states that "constitutional construction should be constrained by the original meaning of the constitutional text." ${ }^{57}$ Both prongs are explicitly wedded to the text.

And the vast majority of today's originalists locate themselves toward the more textual end of the scale. ${ }^{58}$ Thus, originalists often look to historical dictionaries to aid in constitutional interpretation. ${ }^{59}$ And the latest trend in originalist methodology is "corpus linguistics": the use of large historical databases and sophisticated searching techniques designed to better ascertain the public meaning of particular words and phrases at the time of the Framing. ${ }^{60}$ Furthermore, originalist theory increasingly draws upon insights from theoretical linguistics and the philosophy of language,${ }^{61}$ again evincing its unwavering emphasis on the text.

\footnotetext{
${ }^{54}$ Kesavan \& Paulsen, supra note 9, at 1128. For a sophisticated argument that the constitutional text dictates public meaning originalism, see Christopher R. Green, "This Constitution": Constitutional Indexicals as a Basis for Textualist Semi-originalism, 84 Notre DAME L. REV. 1607, 1674 (2009).

55 See Thomas B. Colby \& Peter J. Smith, Living Originalism, 59 DuKE L.J. 239 (2009).

${ }^{56}$ Lawrence B. Solum, Originalism and Constitutional Construction, 82 FordHAM L. REV. 453, 459 (2013).

${ }^{57}$ Id. at 460; see also Jeremy K. Kessler \& David E. Pozen, Working Themselves Impure: A Life Cycle Theory of Legal Theories, 83 U. CHI. L. REV. 1819, 1847 n. 87 (2016) (“Solum has persuasively . . . demonstrated that virtually all self-identified originalists agree in principle on certain core ideas of 'fixation' and 'constraint."'). "Constitutional construction" is discussed in Section III.D, infra.

58 See Richard H. Fallon, Jr., The Many and Varied Roles of History in Constitutional Adjudication, 90 Notre Dame L. Rev. 1753, 1762 (2015). Professors Steven Calabresi and Hannah Begley overstate the case when they assert that "all modern originalists . . are original public meaning textualists." Steven G. Calabresi \& Hannah M. Begley, Originalism and Same-Sex Marriage, 70 U. MiAmi L. Rev. 648, 649 (2016). But not by much.

59 See Gregory E. Maggs, A Concise Guide to Using Dictionaries from the Founding Era to Determine the Original Meaning of the Constitution, 82 GEO. WASH. L. REV. 358, 358 (2014).

60 See James C. Phillips, Daniel M. Ortner \& Thomas R. Lee, Corpus Linguistics \& Original Public Meaning: A New Tool To Make Originalism More Empirical, 126 YALE L.J. F. 21, 24-27 (2016).

${ }^{61}$ See Lawrence B. Solum, Originalist Methodology, 84 U. CHI. L. REV. 269, 276-78 (2017).
} 
In short, to today's mainstream originalists, "it is the objective meaning of the words of the written constitutional text that is the whole ball game." 62 Justice Brett Kavanaugh summed this concept up nicely at his recent confirmation hearings: "Originalism, as I see it, means, in essence constitutional textualism, meaning the original public meaning of the constitutional text."63

\section{The Prevalence of Structural Reasoning In the Conservative CONSTITUTIONAL CANON}

Structural arguments, by contrast, are not rooted in the text. In his classic typology of constitutional interpretive "modalities," Professor Philip Bobbitt explains that "[s]tructural arguments are inferences from the existence of constitutional structures and the relationships which the Constitution ordains among these structures. They are to be distinguished from textual and historical arguments, which construe a particular constitutional passage and then use that construction in the reasoning of an opinion." ${ }^{64}$ As best and most famously described by Professor Charles Black a half-century ago, structural arguments rely on reasoning "sounding in the structure of federal union, and in the relation of federal to state governments," even when the court "can point to no particular text as its authority." 65

This mode of reasoning pervades the conservative constitutional canon, at least in the doctrines addressing questions of governmental power, rather than individual rights. Space constraints limit my ability to document that claim exhaustively here. But it is generally recognized and not, I should think, particularly controversial. So a few examples of federalism and separation of powers cases should suffice.

The Court's reliance on structural reasoning is most obvious in the "new federalism," which "focuses on the original understanding of overall structure rather than particular constitutional provisions." ${ }_{66}$ For instance, the

\footnotetext{
${ }^{62}$ Michael Stokes Paulsen, The Text, the Whole Text, and Nothing but the Text, So Help Me God: Un-writing Amar's Unwritten Constitution, 81 U. CHI. L. REV. 1385, 1385-86 (2014).

63 Randy Barnett, Kavanaugh Testimony, Part 1: On Originalism, VolOKH CONSPIRACY (Sept. 14, 2018, 5:00 PM), http://reason.com/volokh/2018/09/14/kavanaugh-testimony-part-1-on-originalis [https://perma.cc/8CHE-L9X9].

${ }^{64}$ BoBbitT, supra note 20, at 74 .

65 Charles L. Black, JR., Structure and Relationship in Constitutional LaW 11 (1969).

66 Young, supra note 31, at 1603; see also Thomas B. Colby, In Defense of the Equal Sovereignty Principle, 65 DUKE L.J. 1087, 1133 (2016) ("When it comes to fundamental principles of constitutional federalism, a lack of specific textual support is actually par for the course."); Casey L. Westover, Structural Interpretation and the New Federalism: Finding the Proper Balance Between State Sovereignty and Federal Supremacy, 88 MARQ. L. REV. 693, 694 (2005); $c f$. Bradford R. Clark,
} 
Printz case, noted above, found a prohibition against federal commandeering of state executive officials in the "essential postulate[s]" of "the structure of the Constitution," even though there was "no constitutional text speaking to th[e] precise question." ${ }^{67}$ The Alden case, also noted above, is similar. In drawing almost entirely on "fundamental postulates implicit in the constitutional design"68 to preclude Congress from abrogating state sovereign immunity in state courts, Alden, in Professor Ernest Young's words, "drops the textual fig leaf entirely.... The abandonment of textualism is as clear and self-conscious as anyone could wish." ${ }^{\prime 69}$

There are many other federalism cases that rely on the same sort of reasoning. Alden was merely the culmination of a long line of sovereign immunity cases that self-consciously venture far beyond the original meaning of the Eleventh Amendment-the only provision of the Constitution that actually speaks directly to the issue. ${ }^{70}$ In these cases, the Court has openly confessed that its "recognition of sovereign immunity has not been limited to the suits described in the text of the Eleventh Amendment." 71 Rather, to "respect the broader concept of immunity, implicit in the Constitution," the Court has extended the states' immunity to many other categories of suits not mentioned in the constitutional text. ${ }^{72}$

These cases "exemplify the Supreme Court's tendency to define sovereign immunity according to structural, rather than purely textual,

Translating Federalism: A Structural Approach, 66 GEO. WASH. L. REV. 1161, 1161 (1998) ("A panel on federalism does not fit neatly into a Symposium entitled Textualism and the Constitution.").

${ }^{67}$ Printz v. United States, 521 U.S. 898, 918, 905 (1997); see also Brannon P. Denning \& Glenn Harlan Reynolds, Comfortably Penumbral, 77 B.U. L. REV. 1089, 1103 (1997) ("[This] was the sort of inference drawn from the various textual provisions implementing the federal structure that would have made Professor Black ... proud.”)

68 Alden v. Maine, 527 U.S. 706, 707 (1999).

69 Young, supra note 31, at 1602.

70 See Erwin Chemerinsky, The Hypocrisy of Alden v. Maine: Judicial Review, Sovereign Immunity and the Rehnquist Court, 33 LoY. L.A. L. REV. 1283, 1288 (2000).

71 Idaho v. Coeur d'Alene Tribe of Idaho, 521 U.S. 261, 267 (1997).

72 Id. at 267-68; see also Seminole Tribe of Fla. v. Florida, 517 U.S. 44, 54 (1996) ("Although the text of the Amendment would appear to restrict only the Article III diversity jurisdiction of the federal courts, we have understood the Eleventh Amendment to stand not so much for what it says, but for the presupposition . . . which it confirms[:] . . first, that each State is a sovereign entity in our federal system; and second, that [i]t is inherent in the nature of sovereignty not to be amendable to the suit of an individual without its consent." (internal quotation marks and citations omitted)); Pennsylvania v. Union Gas Co., 491 U.S. 1, 31-32 (1989) (Scalia, J., concurring in part and dissenting in part) ("[T]he Eleventh Amendment was important not merely for what it said but for what it reflected: a consensus that the doctrine of sovereign immunity, for States as well as for the Federal Government, was part of the understood background against which the Constitution was adopted, and which its jurisdictional provisions did not mean to sweep away."). 
arguments." 73 The limits on the power of Congress to abrogate state immunity are derived not from the language of the Constitution but rather from the Court's understanding of the broad structure of our federalist system of government. ${ }^{74}$

The sovereign immunity cases are not outliers. Structuralism similarly drives the modern Court's decisions with regard to many other aspects of federalism, including, for instance, the equal sovereignty principle, ${ }^{75}$ Congress's authority to regulate the states through generally applicable regulations, ${ }^{76}$ and federal preemption. ${ }^{77}$

This is hardly a new development. ${ }^{78}$ Structural reasoning in federalism cases goes back at least as far as McCulloch $v$. Maryland, ${ }^{79}$ in which the Court held - despite the complete lack of applicable constitutional text - that the states may not tax an instrumentality of the federal government. Chief Justice John Marshall explained, in colorfully memorable words that quintessentially exemplify structural argument:

There is no express provision for the case, but the claim has been sustained on a principle which so entirely pervades the constitution, is so intermixed with the materials which compose it, so interwoven with its web, so blended with its texture, as to be incapable of being separated from it, without rending it into shreds. ${ }^{80}$

As Professor Charles Black has elucidated, "[i]n this, perhaps the greatest of our constitutional cases, judgment is reached not fundamentally on the basis

\footnotetext{
73 Aman Pradhan, Rethinking the Eleventh Amendment: Sovereign Immunity in the United States and the European Union, 11 N.Y.U. J. LEGIS. \& PUB. POL'Y 215, 220 (2008).

74 See John F. Manning, The Eleventh Amendment and the Reading of Precise Constitutional Texts, 113 YALE L.J. 1663, 1668 (2004); Pradhan, supra note 73, at 220.

75 See Colby, supra note 66, at 1099 ("Nowhere in the Court's terse discussions of equal sovereignty ... does it so much as mention a single provision of the constitutional text.").

76 See Nat'l League of Cities v. Usery, 426 U.S. 833, 852 (1976) (holding that, even though the Commerce Clause would seem textually to allow the regulation at issue, "Congress has sought to wield its power in a fashion that would impair the States' ability to function effectively in a federal system," and that " $[\mathrm{t}]$ his exercise of congressional authority does not comport with the federal system of government embodied in the Constitution" (internal quotation marks and citations omitted)), overruled by Garcia v. San Antonio Metro. Transit Auth., 469 U.S. 528 (1985); BoBBITT, supra note 20, at 75 (explaining that "Usery provides a paradigm of structural constitutional argument").

77 See Gillian E. Metzger, The Constitutional Legitimacy of Freestanding Federalism, 122 HARV. L. REV. 98, 105 n.40 (2009) (arguing that "the presumption against preemption may be the most prominent invocation of freestanding federalism today").

78 See, e.g., Case v. Toftus, 39 F. 730, 732 (C.C.D. Or. 1889) ("The doctrine that new states must be admitted... on an 'equal footing' with the old ones does not rest on any express provision of the constitution . . . but on what is considered . . . to be the general character and purpose of the union of the states ...-a union of political equals.").

7917 U.S. (4 Wheat.) 316 (1819).

$80 \mathrm{Id}$. at 426.
} 
of ... textual exegesis... but on the basis of reasoning from the total structure which the text has created." ${ }^{11}$

The modern conservative Court has also made extensive use of structural reasoning in defining the contours of another fundamental feature of the constitutional design: the separation of powers. ${ }^{82}$ The Court has focused on abstract notions of divided power and checks and balances, in lieu of constitutional text, to decide cases involving a wide range of separation of powers matters, from the legislative veto, ${ }^{83}$ to the nondelegation doctrine, ${ }^{84}$ to Congress's Fourteenth Amendment enforcement power, ${ }^{85}$ to the independent counsel law, ${ }^{86}$ among many others. ${ }^{87}$ All of these decisions assume that "the Constitution contains an

81 BLACK, supra note 65, at 15.

82 See, e.g., John F. Manning, Separation of Powers as Ordinary Interpretation, 124 HARV. L. REV. 1939, 1944 (2011) ("Formalists sometimes [ground their separation of powers decisions] not in any specific understanding of a discrete structural clause, but rather in a general norm of strict separation derived from the document as a whole. In so doing, they reason from general structural inferences to specific limitations on legislative power."); Robert A. Schapiro, Contingency and Universalism in State Separation of Powers Discourse, 4 ROGER WILLIAMS U. L. REV. 79, 90 (1998) (noting that "separation of powers principles often derive from structural inferences, rather than particular textual commands").

83 See BoBBITT, supra note 20, at 82 (noting that the legislative veto "is neither specifically sanctioned nor specifically disapproved by any single provision of the Constitution").

84 See Mistretta v. United States, 488 U.S. 361, 371-72 (1989) (noting that "the integrity and maintenance of the system of government ordained by the Constitution mandate that Congress generally cannot delegate its legislative power to another Branch" (internal quotation marks omitted)); id. at 380 ("In applying the principle of separated powers in our jurisprudence, we have sought to give life to Madison's view of the appropriate relationship among the three coequal Branches."); Manning, supra note 82, at 1963 ( "[The decision in Bowsher v. Synar, 478 U.S. 714 (1986),] did not rest on an established understanding of any particular constitutional clause. Rather, the Court gleaned the purpose of strict separation from the overall structure of, and relationship among, the Vesting Clauses - from the simple fact that the document divides power three ways.").

85 See Denning \& Reynolds, supra note 67, at 1108 ( “[The Court's] conclusions [in City of Boerne v. Flores, 521 U.S. 507 (1997),] rely on the very nature of a written constitution and the separation of powers doctrine inferred from other provisions and suggested by the Constitution's structure. These principles are implicit, not explicit.").

86 See Morrison v. Olson, 487 U.S. 654, 685-97 (1988) (analyzing whether the independent counsel provisions of the Ethics in Government Act of 1978 were "invalid under the constitutional principle of separation of powers"); Panel Discussion: Justice Scalia on Federalism and Separation of Powers at The Federalist Society 2016 National Lawyers Convention (Nov. 17, 2016) reprinted in 30 REGENT U. L. REV. 57, 67 (2017) [hereinafter 2016 National Lawyers Convention] (remarks of John Baker) (explaining that Justice Scalia's dissent in Morrison "may pose a problem for some textualists" because it "starts with the principle of separation of powers," rather than the text of the Constitution, which it treats as merely a "blueprint"); John O. McGinnis, Continuity and Coherence in the Rehnquist Court, 47 ST. LOUIS U. L.J. 875,884 (2003).

87 See, e.g., Bowsher, 478 U.S. at 726 ("The structure of the Constitution does not permit Congress to execute the laws; it follows that Congress cannot grant to an officer under its control what it does not possess.”); Metro. Wash. Airports Auth. v. Citizens for the Abatement of Aircraft Noise, Inc., 501 U.S. 252, 277 n.23 (1991) (relying on "basic separation-of-powers principles," rather than specific constitutional text). 
organizing principle that is more than the sum of the specific clauses that govern relations among the branches." 88

Again, this is nothing new. ${ }^{89}$ The Court's reliance on structure in separation of powers cases goes all the way back to the most iconic case of them all: Marbury v. Madison ${ }^{90}$ in which Chief Justice Marshall referenced various textual provisions, but ultimately "derived the power of judicial review from general understandings of the judicial function and the nature of a written constitution." 91

In sum, the modern conservative majority - building on a long tradition in American constitutional law-believes that, even when there is no particular constitutional provision on point, it has a "responsibility to declare unconstitutional those laws that undermine the structure of government established by the Constitution." ${ }^{92}$

\section{RESOLVING THE CONFLICT?}

There would seem to be an obvious conflict here. To the extent that originalists continue to endorse, even silently, structural decisions that generate policy results that they favor, yet seem to run afoul of their avowed, indeed ballyhooed, methodological commitment to the constitutional text, they invite skepticism about the intellectual rigor and consistency of the entire originalist project. ${ }^{93}$

So then, what is a committed and intellectually honest originalist to do?

\section{A. Denying the Conflict: Structuralism as Holistic Textualism}

Many originalists, I suspect, would respond by denying the premiseby asserting that there is, in fact, no conflict at all. They would maintain that structural argument is not conceptually or jurisprudentially distinct from textual argument; rather, it is simply a particular kind of textual argumentand one that is perfectly consistent with the new originalism. Because the

88 Thomas W. Merrill, The Constitutional Principle of Separation of Powers, 1991 SUP. CT. REV. $225,225$.

89 See, e.g., United States v. Nixon, 418 U.S. 683, 707 (1974) (concluding, in the absence of constitutional text on point, that an absolute executive privilege "would upset the constitutional balance of 'a workable government' and gravely impair the role of the courts under Art. III'); Youngstown Sheet \& Tube Co. v. Sawyer, 343 U.S. 579, 635 (1952) (Jackson, J., concurring).

905 U.S. (1 Cranch) 137 (1803).

91 Metzger, supra note 77, at 104.

92 Nat'l Fed'n of Indep. Bus. v. Sebelius, 567 U.S. 519, 559 (2012) (opinion of Roberts, C.J.).

93 See supra text accompanying note 36; see also Rappaport, supra note 31, at 821 ("But if conservatives are seen as departing from text in order to promote federalism, they will be open to the charge of inconsistency if not hypocrisy, of pursuing their own political agenda under the cover of inconsistently applied neutral principles."). 
structure of our government is set out in the constitutional text, the argument would go, claims about the functional and doctrinal implications of that structure are ultimately derived from the text.

Certainly, some originalists have viewed structural argument in these terms. Professor Michael Paulsen and Luke Paulsen, for instance, argue that, "[i]n a sense, reasoning from constitutional structure is a variation on the theme of emphasis on the written text: it simply considers the text as a whole, and the relationships and implications created by its constituent parts." 94 When the Court decides a case on the basis of a structural principle, it typically looks to a variety of textual provisions and ultimately concludes that, although that principle is not found in the original meaning of any particular clause, it nonetheless "is reflected throughout the Constitution's text." 95

Perhaps it is as simple as that. Structural argument is textual argument. Problem solved. Conflict averted.

But to Professor Charles Black, the undisputed academic champion of structuralism, structural argument and textual argument are fundamentally distinct. "There is," Professor Black conceded, "a close and perpetual interworking between the textual and the relational and structural modes of reasoning, for the structure and relations concerned are themselves created by the text, and inference drawn from them must surely be controlled by the text." ${ }^{96}$ Yet the entire thrust of his book is that structural argument is not textual argument. ${ }^{97}$

Similarly, Professor Bobbitt recognizes that "the structural approach... is grounded in the actual text of the Constitution"- "a macroscopic view of the text"-but asserts that structural argument is an analytically distinct interpretive modality because it reasons "from an entire Constitutional text rather than from one of its parts." 98

\footnotetext{
94 Michael Stokes Paulsen \& Luke Paulsen, The Constitution: An Introduction 28 (2015).

95 Printz v. United States, 521 U.S. 898, 919 (1997); see Manning, Foreword, supra note 11, at 35 (noting that, in Printz, "the Court's major premise was that the constitutional text as a whole established a broad background value of 'dual sovereignty' from which the Court could infer a specific prohibition against commandeering").

${ }^{96}$ BLACK, supra note 65 , at 31 .

97 See id. at 7-8 (noting that "the method of purported explication or exegesis of the particular textual passage" is "opposed to the method of inference from the structures and relationships created by the constitution"); Akhil Reed Amar, Architexture, 77 IND. L.J. 671, 699 n.104 (2002) ("Black explicitly defined his brand of 'structural' interpretation in contradistinction to textualism.").

98 BoвbitT, supra note 20, at 80, 85, 74 .
} 
Of course, this might just be a matter of taxonomic semantics. The operative question is whether structural argument is a form of textual argument within the meaning of original public meaning textualism.

To explore that question further will necessitate greater precision in defining structural reasoning. At the broadest level, we can distinguish between two types of reasoning that have often been labeled as "structural": (1) looking to the structure of the Constitution itself in order to determine the meaning of a particular provision thereof; and (2) looking to the structure and relationships between the institutions described in the Constitution in order to discover limits on government action that do not run afoul of any particular constitutional provision. ${ }^{99}$

Professor Dorf refers to the first type of reasoning as "interpretive holism"100 - interpreting particular passages in light of the document as a whole. This is a species of textual argument, and one that poses no conflict for committed public meaning originalists. ${ }^{101}$ Professor Solum, who has carefully considered the relationship between public meaning originalism and unwritten constitutional rules, has developed this point in some detail, explaining the various ways in which the structure of the document can help to inform the meaning of particular clauses:

1. Reading parts of the Constitution in light of the whole can resolve semantic ambiguities.

2. Reading parts of the Constitution in light of the whole can reveal constitutional implications - the logical consequences of the interactions between various clauses.

99 This distinction has been drawn by a number of commentators. See Dorf, supra note 20, at 834 38; Manning, Generality, supra note 11, at 2067-68; Young, supra note 31, at 1631-34.

100 Dorf, supra note 20, at 833.

101 See id.; Calabresi \& Prakash, supra note 22, at 553 ("Consider the plain meaning of the words of the Constitution, remembering to construe them holistically in light of the entire document." (footnote omitted)); Bradford R. Clark, Federal Lawmaking and the Role of Structure in Constitutional Interpretation, 96 CALIF. L. REV. 699, 720 (2008); Clark, supra note 66, at 1161 (“" [T]he constitutional text may provide less than complete guidance. In resolving such ambiguities, it is useful - if not essential-to determine the specific import of the constitutional text by reference to the constitutional structure."); Manning, Generality, supra note 11, at 2067 (noting that "[m]odern textualists readily embrace" the "proposition that when a ... provision is semantically indeterminate, its meaning can sometimes be illuminated by considering its fit with, and functional relationship to, other provisions of the text"); John O. McGinnis, Originalism Encompasses Text and Structure, LAW \& LiBERTY (Aug. 21, 2018), https://www.lawliberty.org/2018/08/21/originalism-encompasses-textual-and-structuralmodalities-pamela-karhan [https://perma.cc/B2FX-CNRZ] ("Most originalists would agree that the meaning of the Constitution is not clause-bound and that the structure of the entire document could sometimes be relevant to resolving the original meaning of texts that might otherwise be unclear."). 
3. Reading parts of the Constitution in light of the whole can create or reveal contextual enrichment-in this regard the whole text acts as context for particular clauses, phrases, or words. ${ }^{102}$

In sum, public meaning originalism clearly endorses "read[ing] individual clauses in the context of the whole Constitution," including the "structural features of the constitutional text." 103

It is possible that some of the modern Court's ostensibly structural cases simply employ the sort of holistic textual analysis that ought not be concerning to originalists - using the structure of the document to help determine the original meaning of otherwise vague or ambiguous provisions of the constitutional text. ${ }^{104}$

But many of the cases clearly go beyond this type of argument and employ the second type of structural reasoning. These cases do not use the structure of the document itself in order to better ascertain the meaning of a particular provision contained within it. Rather, they use the structure of the constitutional system established by the document in order to derive a rule that is not tethered to, or dictated by, the meaning of any one provision. That is true structural reasoning, of the type championed by Professor Charles Black. ${ }^{105}$ As Professor Dorf explains, instead of being drawn from the Constitution's text, "whether interpreted clause-by-clause or holistically," Black insists that true structural reasoning "emerge[s] out of the institutions the Constitution creates or recognizes, rather than directly from the text." 106

\footnotetext{
102 Solum, supra note 1, at 1965.

103 Id. at 1964-65. For instance, Akhil Amar's "intratextualism"- the holistic process of "read[ing] a contested word or phrase that appears in the Constitution in light of another passage in the Constitution featuring the same (or a very similar) word or phrase," Akhil Reed Amar, Intratextualism, 112 HARV. L. REV. 747, 748 (1999) — is generally accepted by originalists. See Michael D. Ramsey, Missouri v. Holland and Historical Textualism, 73 Mo. L. ReV. 969, 972 (2008) ("Nothing in the idea of textualism is inconsistent with the idea of looking throughout the entire text for clues to meaning of particular clauses; to the contrary, that is a core component."). But see William Michael Treanor, Taking Text Too Seriously: Modern Textualism, Original Meaning, and the Case of Amar's Bill of Rights, 106 MICH. L. REv. 487, 487 (2007) (arguing that intratextualism cannot be squared with the original public meaning).

104 I suspect, though, that most of the cases that could be characterized in this way might better be thought of as examples of a different interpretive phenomenon: the textual hook. See infra Section III.C.

105 See Dorf, supra note 20, at 835-36.

${ }^{106} \mathrm{Id}$. at 836. This form of reasoning is, in substantial part, what Chief Justice Marshall was getting at when he cautioned that "we must never forget, that it is a constitution we are expounding." McCulloch v. Maryland, 17 U.S. (4 Wheat.) 316, 407 (1819). "[O]nly its great outlines should be marked, its important objects designated, and the minor ingredients ... deduced from the nature of the objects themselves." Id.; see Craig Green, Erie and Problems of Constitutional Structure, 96 CALIF. L. REv. 661, 685 (2008).
} 
Many of the Court's structural cases-Printz, Alden, and Shelby County v. Holder ${ }^{107}$ among the most obvious - unquestionably fall into this category of true structural reasoning, "drawing operative rules directly from structure, rather than restricting structural argument to the role of informing interpretation of particular texts." 108 They articulate, in Professor Craig Green's words, "a vision of constitutional structure wherein respect for federalism and separation of powers transcends preoccupation with constitutional text." 109

One could characterize this mode of reasoning as "textualist," I suppose, in that it derives "from the total structure which the text has created." 110 "And the structure is of course made by the specific provisions." "111 But the connection to the text is simply the fact that the text establishes the structure. Other than that, the reasoning is from the structure of the governmental system established by the text, not the text itself. Sometimes the Court looks to various textual provisions in the course of that reasoning, but not with the purpose of determining their meaning, and not with the understanding that any one of them will control the decision. The Court looks to those provisions only to determine the structural architecture of the system. The architecture itself then provides the basis for the decision. Put differently, true structuralism reasons up from specific provisions that admittedly do not control the decision to ascertain broader structural principles said to inhere in the document or the governmental system as a whole, which principles are then applied to formulate a rule of decision. ${ }^{12}$

107570 U.S. 529, 544 (2013) (declaring without reference to any provision of the text that "there is . . . a fundamental principle of equal sovereignty among the States" (internal quotation marks omitted)).

108 Young, supra note 31, at 1636; see, e.g., Manning, Generality, supra note 11, at 2068 (arguing that the interpretive technique in which "the overall structure takes on a life of its own, providing the source for values that are attached to no particular clause of the document but are nonetheless enforceable as law" is what "characterizes the new federalism cases"); Ramsey, supra note 33, at 1952 ("Scalia's application of nontextual assumptions came in cases where ... the text itself had no direct bearing on the case"); id. ("Printz uses structural reasoning to develop a rule Scalia acknowledged was not found in the text. And the immunity cases, the most aggressive example, use background assumptions and structural reasoning to overcome what may appear to be the most natural reading of the text.").

109 Green, supra note 106, at 685.

110 BLACK, supra note 65, at 15.

111 John Harrison, Book Review: Review of Structure and Relationship in Constitutional Law, 89 VA. L. REV. 1779, 1786 (2003).

112 See Manning, Generality, supra note 11, at 2005-06 ("This is not to say that the Court in these cases forswears the constitutional text altogether.... [W] hat makes the new federalism decisions so interesting is that the Court seeks the founders' decisions not in the meaning of any discrete clause, but in the overall system of government they adopted in the document. This technique, a form of structural inference, identifies numerous discrete provisions that, in particular ways, divide sovereign power between state and federal governments and, in so doing, preserve a measure of state autonomy. Taking all of those provisions together, the Court ascribes to the document as a whole a general purpose to preserve a significant element of state sovereignty."). 
Professor Paulsen has suggested that this process is textual enough to comport with the fundamental precepts of the new originalism. The "sole object of constitutional interpretation" remains the text, but it is "the whole text,... including the relationships and interactions among differing provisions, the structures of government it creates, the logic of its arrangements, and the inferences that fairly can be drawn from its provisions." 113 "It is not at all improper constitutional interpretation," he argues, "to deduce from the document certain rules of law that flow logically from others contained in the text or discernible from its structure and operation," 114 because those rules are "justified, ultimately, by the constitutional text." 115

But I am skeptical. As Professor Michael Rappaport has succinctly put it, "constitutional structure, while a useful aid to interpretation, is not itself text." ${ }^{116}$ One could characterize virtually any constitutional argument, no matter how nonoriginalist, as grounded ultimately in the basic relationships set out in the text of the Constitution among the people, the states, and the federal government and as seeking to ensure that those fundamental relationships continue to function effectively in service of the values that underlie the entire constitutional order. ${ }^{117}$ But that doesn't make it a textual argument. ${ }^{118}$

To analogize to the realm of statutory interpretation, imagine an argument that proceeds along the following lines: Congress created a particular federal agency by statute; that statute defines the contours of the relationship between the agency, the regulated entities, and the people. The agency would not be able to fulfill completely its mission of protecting the people from all dangers that fall generally within the subject matter of its broad regulatory ambit unless it were able to forbid a particular practice. Therefore, the statute should be construed to allow the agency to regulate

113 Paulsen, supra note 62, at 1389.

114 Id. at 1394

115 Id.; cf. Michael Coenen, Combining Constitutional Clauses, 164 U. PA. L. REV. 1067, 1111-12 (2016) (arguing that "the value of textual fidelity" is sometimes enhanced by structural reasoning).

116 Rappaport, supra note 31, at 820; see also Richard Primus, Unbundling Constitutionality, $80 \mathrm{U.}$ CHI. L. REV. 1079, 1129-30 (2013) (arguing that structural reasoning does not comport with constitutional textualism); Ramsey, supra note 103, at 973 n.20 (noting "that textualism and structuralism overlap, but not completely: some so-called structural arguments are textual and some are not").

117 See, e.g., Robert F. Schopp, Education and Contraception Make Strange Bedfellows: Brown, Griswold, Lochner, and the Putative Dilemma of Liberalism, 32 ARIZ. L. REV. 335, 345 (1990) (arguing that the right to privacy "defines a conception of the proper relationship between the individual and the government").

118 And by the same token, an argument that seeks the original understanding of the structural relationships set up by the Constitution, but is not tied to any particular provision of the text, might be an originalist argument, but it is not an original public meaning argument. 
that practice even though the agency's regulatory powers are set out in detail in the statute, and there is no provision that could plausibly be read to empower the agency to do so. Whatever else we might say about that argument, we wouldn't call it a textual one.

One can also analogize - unfavorably from the perspective of most originalists - to the loose reasoning of the Warren Court in rights cases. That Court famously defended a general right to privacy in the Constitution on the ground that "specific guarantees in the Bill of Rights have penumbras, formed by emanations from those guarantees that help give them life and substance." 119 While no particular provision of the Bill of Rights protects a right to contraception, the Court nonetheless found that right "lying within the zone of privacy created by several fundamental constitutional guarantees"120_within, that is, "the Bill of Rights as a whole." 121

The Court's methodology in discovering particular principles of federalism and separation of powers within the "Constitution as a whole," though not within any particular provision of it, is uncomfortably similar. ${ }^{122}$ Indeed, after Justice Scalia delivered the Court's opinion in Printz from the bench, Justice Stevens, before reading his dissent, "remarked spontaneously that Justice Scalia's opinion for the Court reminded him of Justice Douglas's opinion in the Griswold contraceptives case of 1965, which extrapolated a right to privacy from the Constitution's 'penumbras' and 'emanations." 123

While these penumbral arguments may have their pros and cons, at the very least, we should be able to agree that they do not evince the methodology of mainstream public meaning originalism. To the contrary, thoughtful and sophisticated originalists have tended to view Griswold's

119 Griswold v. Connecticut, 381 U.S. 479, 484 (1965).

$120 \mathrm{Id}$. at 485.

121 J. Richard Broughton, Unforgettable, Too: The (Juris)prudential Legacy of the Second Justice Harlan, 10 Seton HaLl Const. L.J. 57, 94 (1999).

122 See Baude, supra note 32, at 7 (noting that structural arguments pose "a difficulty for those who claim that it is the written document, not its penumbras and emanations, that supplies our constitutional law"); Edward Cantu, The Roberts Court and Penumbral Federalism, 64 CATH. U. L. REV. 271, 274 (2015); Denning \& Reynolds, supra note 67, at 1096 (comparing McCulloch and Griswold: "the methodologies used in both cases are virtually indistinguishable"); Manning, Generality, supra note 11, at 2005 (referring to the new federalism cases as enforcing "unenumerated states' rights"); Timothy Zick, Statehood as the New Personhood: The Discovery of Fundamental "States' Rights," 46 WM. \& MARY L. REV. 213, 221 (2004).

123 Jeffrey Rosen, Dual Sovereigns, NEw REPUBLIC (July 27, 1997), https://newrepublic.com/article 174153/dual-sovereigns [https://perma.cc/YGD5-GEC4]; see also 1 LAURENCE H. TRIBE, AMERICAN CONSTITUTIONAL LAW $\S 1-13$, at 44 (3d ed. 2000). 
penumbral reasoning as "one of the most famously outlandish arguments in all of constitutional law." 124

Public meaning originalism seeks to find "the original meaning of $a$ constitutional provision," 125 not the Constitution as a whole. It seeks to uncover the meaning of particular "words and phrases from the late eighteenth century and from the mid-nineteenth century for the Reconstruction Amendments." 126 In Professor Kurt Lash's words, "originalism requires the writer to identify the specific text that establishes a particular meaning." ${ }^{127}$ Thus, when "scholars are unable to find a particular meaning linked to one specific text, and so attempt to link a claimed 'original meaning' to a combination of texts," or to the constitutional structure as a whole, they "have not made a broadly acceptable originalist argument." 128

As Professor Ramsey has put it, to a public meaning originalist, " $[t]$ he historical meaning of the whole is not more than the historical meaning of the sum of its clauses." ${ }^{22}$ Professor Ramsey contrasts using "what Professor Charles Black's foundational work called 'the constitution in all its parts' to illuminate the meaning of a particular part" with "find[ing] meaning in "the general themes of the entire constitutional document' (as John Ely put it) without relating them back to particular words and phrases." 130 "Both approaches may be called "structural'," he explains, "but for a textualist there should be a manifest distinction." ${ }^{131}$ A method of constitutional argument that does not seek to determine and apply the original meaning of the text of a particular constitutional provision is not a form of public meaning originalism as that theory is generally understood.

There is, indeed, a conflict between the new originalism and structural argument.

\footnotetext{
124 Nelson Lund \& John O. McGinnis, Lawrence v. Texas and Judicial Hubris, 102 Mich. L. REV. 1555, 1569 (2004); see also id. at 1597 (“The Griswold-Roe-Lawrence line of cases has no apparent basis in the text or original meaning ... and the Justices have never tried to show that there is one."); Mark Pulliam, Unleashing the "Least Dangerous" Branch: Quis Custodiet Ipsos Custodes?, 22 TEX. REv. L. $\&$ POL. 423, 441 (2018) ("Most originalists properly scoff at the search for "penumbras' . ...").

125 Lawrence B. Solum, District of Columbia v. Heller and Originalism, 103 Nw. U. L. REv. 923, 926 (2009) (emphasis added).

${ }^{126}$ Lawrence B. Solum, Surprising Originalism: The Regula Lecture, 9 ConLawNOW 235, 246-47 (2018).

127 Kurt T. Lash, Safe Harbor Originalism, LAw \& LIBERTY (Feb. 12, 2015), www.libertylawsite.org /2015/02/12/safe-harbor-originalism [https://perma.cc/Z935-5KAJ].

${ }^{128} \mathrm{Id}$.

129 Ramsey, supra note 103, at 972 (noting that a originalist "textualist will be skeptical of conclusions supposedly based on an abstract constitutional 'structure' or 'purpose' but not tied to particular words and phrases").

${ }^{130} I d$. at 973 (footnotes omitted).

${ }^{131} I d$.
} 


\section{B. Averting the Conflict: Rejecting Structural Reasoning}

Perhaps originalists should stop trying to have it both ways, then. Perhaps they should bite the bullet, admit that pure structural reasoning (as opposed to holistic textualism) is not compatible with public meaning originalism, and abandon the former so as to maintain a commitment to the latter. One scholar who has advocated doing so is Professor Manning. ${ }^{132}$ Manning argues that structural argument cannot be reconciled with textualism and all of the compelling reasons that lead people, including new originalists, to be textualists should lead them to reject structural arguments as well. ${ }^{133}$

That would certainly dissipate the conflict. But I suspect that it is simply not a palatable option for most originalists - which explains why Manning has been something of a lone voice in the wilderness lo these many years, despite the intellectual heft of his arguments. Simply put, abandoning structural reasoning would require rejecting too many precedents that today's conservatives hold dear. ${ }^{134}$ Of course, many originalists, including some of the leading originalist theorists, are not politically conservative. ${ }^{135}$ And those who are conservative no doubt try very hard to separate their constitutional views from their political ones. But for many originalists - as for all of us - the subconscious temptation to find some way to reconcile the two may be difficult to overcome.

Moreover, abandoning structural argument altogether runs the risk of producing absurd results that could threaten the viability of our entire constitutional system. "[S]ome things just have to be true of the Constitution for it to fulfill its functions effectively, regardless of whether those things are spelled out in the text." 136 Professor Charles Black asks, "Could a state make it a crime to file suit in a federal court? Could a state provide that lifelong

\footnotetext{
132 Professor Manning has not, as far as I know, publicly self-identified as an originalist, though Justice Scalia thought of him as one. See David Bernstein, Speaking of the Scalia Interview . . Three Originalists on the Harvard Faculty?, VOLOKH CONSPIRACY (Oct. 7, 2013), http://volokh.com /2013/10/07/speaking-scalia-interview-three-originalists-harvard-faculty [https://perma.cc/LT3DFZFN]. But he is certainly a textualist, and he has written that "statutory textualists are originalists in matters of constitutional law." John F. Manning, Textualism and the Equity of the Statute, 101 CoLUM. L. REV. 1, 8 (2001).

133 See Manning, Generality, supra note 11, at 2037-67; Manning, supra note 82, at 1971-2005; Manning, supra note 74, at 1665; see also infra notes 205-212 and accompanying text. As Professor Gillian Metzger explains, "Manning carefully and methodically constructs a powerful case . . broadly against the use of nontextually tethered structural inferences in all constitutional interpretation." Metzger, supra note 77 , at 99.

134 See supra Part II.

135 See Ofer Raban, Between Formalism and Conservatism: The Resurgent Legal Formalism of the Roberts Court, 8 N.Y.U. J.L. \& LIBERTY 343, 345 n.3 (2014).

136 Colby, supra note 66, at 1146 n.271.
} 
disqualification from voting or holding property was to result from even a short service in the United States Army?" 137 For that matter, could a state tax an instrumentality of the federal government? ${ }^{138}$ Can states secede from the Union? ${ }^{139}$ Not if our Constitution and our government are going to "endure for ages to come." 140

Most originalists would, I imagine, prefer to find a way to incorporate structural argument into their jurisprudence.

\section{Eluding the Conflict: Textual Hooks}

One possibility for incorporating structural argument into public meaning originalism immediately presents itself. If freestanding structural arguments are not compatible with the new originalism, but holistic textual arguments are, then the solution might be to convert nontextual structural arguments into holistic textual ones. One could latch the structural claim on to a particular hook in the text and then claim that the structure dictates the original meaning of that particular clause.

Conceptually, this approach is methodologically distinct from legitimate interpretive holism in that it starts with the structure, and then seeks to find a textual provision in which to anchor it, ${ }^{141}$ rather than starting with a particular textual provision, and then looking to the structure to help ascertain its original meaning. ${ }^{142}$

In practice, of course, it can be difficult to distinguish between the two. Scholars and judges are not likely to openly confess, "In truth, I am basing this conclusion on abstract notions of constitutional structure, but since some people feel uncomfortable with that, here is a textual provision that you can go ahead and latch on to if it makes you feel better." ${ }^{143}$ They are far more likely to claim the mantra of text, even when the structure is really doing the work. ${ }^{144}$ As Professor Don Regan once memorably wrote, "[j] ust as 'nature

137 BLACK, supra note 65, at 12.

138 See McCulloch v. Maryland, 17 U.S. (4 Wheat.) 316, 407 (1819).

139 See Texas v. White, 74 U.S. 700 (1869).

140 McCulloch, 17 U.S. at 415.

141 Cf. Robert Brauneis, “The Foundation of Our 'Regulatory Takings' Jurisprudence”: The Myth and Meaning of Justice Holmes's Opinion in Pennsylvania Coal Co. v. Mahon, 106 YALE L.J. 613, 698 (1996) ("Judges and scholars, however, have rarely been able to resist the temptation to read broader protections of property into the Constitution, whether the chosen textual hook is the Contract Clause, the Due Process Clause, or the Takings Clause.").

142 Cf. supra notes 100-104 and accompanying text (discussing interpretive holism).

143 But see Colby, supra note 66, at 1142-45 (doing just that with regard to the equal sovereignty principle). But I'm weird. And I'm not an originalist.

144 See BLACK, supra note 65, at 12; BOBBITT, supra note 20, at 75; cf. Clark, supra note 101, at 729 (rejecting a charge that he is employing structural reasoning by casting his argument as an interpretation 
abhors a vacuum,' so we are taught to abhor constitutional principles without a specific textual grounding. When such a principle is implicated in some case, we therefore rush in with misguided suggestions for a textual grounding inspired by the context of the case at hand." 145

By placing more weight on the original meaning of the textual hook than that one clause can safely bear, however, that approach produces decisions and arguments that end up looking weak, results-oriented, and too clever by half. ${ }^{146}$ Many of the modern Court's federalism and separation of powers decisions are susceptible to this charge. ${ }^{147}$ Most obvious might be New York v. United States, ${ }^{148}$ in which the Court attempted to ground the anti-commandeering doctrine in the Tenth Amendment, rather than abstract notions of constitutional structure, despite the fact that such a reading flies in the face of the actual text of the amendment. ${ }^{149}$

Relatedly, originalists could seek textual authorization for structural reasoning generally. And some very good originalist scholarship has done just that - packing particular constitutional provisions to the very brim with structuralist cargo. Professor Rappaport, for instance, has insisted that the anti-commandeering doctrine, state sovereign immunity, and state immunity from federal regulation can all be safely grounded in the original meaning of the word "State." 150 Professor Gary Lawson and Patricia Granger have argued that the word "proper" in the Necessary and Proper Clause "serves as

of a particular provision); David A. Strauss, Foreword: Does the Constitution Mean What It Says?, 129 HARV. L. REV. 1, 12 (2015).

145 Donald H. Regan, Siamese Essays: (I) Cts Corp. v. Dynamics Corp. of America and Dormant Commerce Clause Doctrine; (II) Extraterritorial State Legislation, 85 MiCH. L. REv. 1865, 1889 (1987); see also Brannon P. Denning, Why the Privileges and Immunities Clause of Article IV Cannot Replace the Dormant Commerce Clause Doctrine, 88 MINN. L. REV. 384, 413-14 (2003) (noting that courts often "seem bent on finding a textual hook for what, in essence, is a structural principle").

146 See BoBBITT, supra note 20, at 76 (noting that these arguments end up looking "absurd"); Primus, supra note 116, at 1130 ("[I]t is possible to find a tremendous amount in the text if one is willing to entertain sufficiently tendentious textual interpretations. But constitutional rules like the ones listed above are more straightforwardly explained in structural terms, such that accepting the legitimacy of structural, nontextual constitutional authority exempts one from having to endorse awkward textual readings."); Zephyr Teachout, The Anti-corruption Principle, 94 CoRnEll L. REv. 341, 402 (2009) ("Efforts to ground the separation-of-powers principle in particular phrases, instead of in the spirit of the document, end up sounding warped and feeling disingenuous.").

147 See, e.g., Manning, Foreword, supra note 11, at 47.

148505 U.S. 144 (1992); see also Fry v. United States, 421 U.S. 542, 547 n.7 (1975) (articulating the view that, despite its phrasing as a truism, the Tenth Amendment actually serves as a textual anchor for "the constitutional policy that Congress may not exercise power in a fashion that impairs the States' integrity or their ability to function effectively in a federal system").

149 See Manning, Generality, supra note 11, at 2063; Rappaport, supra note 31, at 826-27.

150 See Rappaport, supra note 31, at 821; Young, supra note 31, at 1624 ("Rappaport feels strongly that the Court's state sovereignty jurisprudence must have some textual basis in the Constitution, and he finds one in the meaning of the word 'state' as used in the original document."). 
a textual guardian of principles of separation of powers, principles of federalism, and unenumerated individual rights." 151 And Professor Deborah Merritt has argued that the Guarantee Clause justifies much of the Court's federalism jurisprudence because it "may simply be the 'textual embodiment' of structural concerns reflected in the Constitution as a whole." 152

These are serious (and seriously good) scholarly monographs, drawing deftly upon history and structure. As Professor Young has shown, "the particular textual term" in these arguments "serves as a shorthand for structural considerations rather than a font of meaningful textual analysis." 153 They are quintessential examples of seeking to "provide a textualist hook for structural arguments." ${ }^{154}$ However, it seems like a stretch to assert that the readings that they offer are, in fact, the original meanings of the constitutional provisions that they purport to interpret - that those seemingly innocuous provisions originally smuggled numerous, wide-ranging, largescale structural principles into the Constitution wholesale, thereby significantly curtailing federal regulatory authority in countless unarticulated ways. ${ }^{155}$

These textual hooks do "not so much give us a textual indication of what the unwritten structural principles of federalism [or separation of powers] are as [they] give us a textual anchor for reading those structural principles-whenever we find them elsewhere-into the constitutional text." ${ }^{156}$ As such, originalists who oppose large portions of the Court's unenumerated rights jurisprudence must tread lightly here. If textual hooks

151 Gary Lawson \& Patricia B. Granger, The "Proper" Scope of Federal Power: A Jurisdictional Interpretation of the Sweeping Clause, 43 DuKE L.J. 267, 271-72 (1993). This argument has been picked up by the Justices. See Nat'l Fed'n of Indep. Bus. v. Sebelius, 567 U.S. 519, 559 (2012) (opinion of Roberts, C.J.) (arguing that "those laws that undermine the structure of government established by the Constitution... are not proper means for carrying into Execution Congress's enumerated powers" (citation, brackets, and internal quotation marks omitted)).

152 Deborah Jones Merritt, The Guarantee Clause and State Autonomy: Federalism for a Third Century, 88 Colum. L. ReV. 1, 2 n.8 (1988).

153 Young, supra note 31, at 1624.

154 Id. at 1630.

155 See, e.g., Baude, supra note 32, at 7 ("This theory has the virtue of pointing to an actual textual provision, but it still requires packing a single word with an awful lot of freight." (discussing Professor Rappaport)); J. Randy Beck, The New Jurisprudence of the Necessary and Proper Clause, 2002 U. ILL. L. REV. 581 (questioning Lawson and Granger's interpretation of the Necessary and Proper Clause); Stephen E. Sachs, Constitutional Backdrops, 80 GEO. WASH. L. REV. 1813, 1873 (2012) ("Though states may in fact have had such immunity, and courts may in fact have respected it, it's far from clear that those facts were linguistic ones about the meaning of 'State' or 'judicial Power,' rather than features of the objects to which those terms referred." (discussing Professor Rappaport)).

156 Colby, supra note 66, at 1145; see also Manning, Generality, supra note 11, at 2062; Young, supra note 31 , at 1629 . 
can be used to warrant the existence of unenumerated principles of government structure, then they can be used to anchor unenumerated rights as well. As a matter of original meaning, the argument for anchoring freestanding liberties - the contents of which are found outside of the document - in the Ninth Amendment, the Privileges or Immunities Clause, or even the Due Process Clauses, is every bit as strong as the argument for anchoring freestanding principles of federalism or separation of powers in any particular constitutional provision. ${ }^{157}$

\section{Tolerating the Conflict: Acknowledging a Large Construction Zone}

Originalists need not stretch the text in less-than-fully-convincing ways in order to reconcile structural reasoning with public meaning originalism, however. They can, instead, reach the same results by using structure to guide the task of constitutional construction.

Many new originalists draw a distinction between constitutional interpretation, "the activity that discerns the communicative content (linguistic meaning) of the constitutional text," and constitutional construction, "the activity that determines the content of constitutional doctrine and the legal effect of the constitutional text." ${ }^{158}$ Much of the time, the original meaning of the text — due to vagueness, ambiguity, or some other form of indeterminacy — does not dictate decisive answers to constitutional questions. Rather, there are multiple possible rules of decision that are each consistent with the vague, open-ended, or ambiguous original meaning. When that happens, the decision-maker finds himself in a realm of uncertainty, in which original meaning cannot, on its own, resolve the case. New originalists have dubbed that realm "the construction zone." 159 When operating within the construction zone, judges must, by definition, turn to sources or principles outside of the underdeterminate original meaning of the text to resolve the case. ${ }^{160}$ Since interpreting the text alone does not get the

157 See AKhil ReEd Amar, America's Unwritten Constitution: The PreCEDEnTS AND PRINCIPLES We LiVE BY, at xi (2012) (opining that, due to the Ninth Amendment, fidelity to the text requires recognizing unenumerated rights); BARNETT, supra note 51, at 108 (arguing that the "original meaning of the terms of the Constitution as amended - such as the Ninth Amendment or the Privileges or Immunities Clause - might well authorize supplementation of its express terms"); Frederick Mark Gedicks, An Originalist Defense of Substantive Due Process: Magna Carta, Higher-Law Constitutionalism, and the Fifth Amendment, 58 EMORY L.J. 585, 588 (2009) (discussing the proposition that the Due Process Clauses of the Fifth and Fourteenth Amendments constitutionalized unenumerated substantive rights); Michael W. McConnell, Ways to Think About Unenumerated Rights, 2013 U. ILL. L. REV. 1985, 1986 (discussing the possibility the Ninth Amendment and the Privileges or Immunities Clause might support a jurisprudence of broadly accepted traditional rights).

158 Solum, supra note 56, at 457.

159 Id. at 458.

160 See id. at $472-73$. 
job done, judges must construct doctrine that will generate a rule of decision "that is consistent with . . original meaning but not deducible from it." ${ }^{161}$

The construction zone is an ideal worksite for structural argument. ${ }^{162}$ Textual hooks are often a bridge too far, because they unconvincingly overargue that the single and true original meaning of particular constitutional provisions just happens to reflect structural principles that are not genuinely enumerated in the text. ${ }^{163}$ It is much more convincing to argue that the particular constitutional provision, though ambiguous, could fairly be read to reflect or encompass the structural principles, rather than that it must be read to do so. Or that the original meaning of the provision could be read to countenance a broad range of possible rules, and that judges, in choosing among those possible rules, should select the ones that are most consistent with the constitutional structure.

That is the approach that Professors Randy Barnett and Evan Bernick take in a recent article, in which they offer "an originalist theory of constitutional construction: good faith originalist construction," which "seeks to implement the Constitution faithfully by ascertaining and adhering to the original functions of the constitutional text-its 'spirit." 164 According to Barnett and Bernick, in constitutional interpretation, judges must adhere to the Constitution's letter-its original meaning. ${ }^{165}$ In the construction zone, judges should adhere to the Constitution's spirit. ${ }^{166}$ They should

identify the original functions or spirit of the provision, and formulate a rule ... that is consistent with the letter and designed to implement the original functions of the provision at issue or, failing that, the structure in which the provision appears or, failing that, the Constitution as a whole. ${ }^{167}$

Using structure to guide construction is an ideal way to follow and respect the Framers' institutional design without running afoul of the originalist commitment to the original meaning of the constitutional text as the sole determinant of constitutional meaning. Construction follows interpretation. ${ }^{168}$ According to this approach, the interpretation of the

\footnotetext{
161 BARNETT, supra note 51, at 121.

162 See Solum, supra note 1, at 1962-67 (providing a detailed discussion of how holism and structure can be used in the construction zone).

163 See supra Section III.C.

164 Randy E. Barnett \& Evan Bernick, The Letter and the Spirit: A Unified Theory of Originalism, 107 GEO. L.J. 1, 5 (2018) (emphasis omitted).

165 See id. at 33-34.

166 See id. at 34.

$167 \mathrm{Id}$. at 35 (outlining omitted).

168 But cf. Solum, supra note 56, at 495 (observing that, while the theoretical model for interpretation and construction illustrates a sequential process, "real judges might begin with construction, move back to interpretation, and then revise the construction — or do both more or less simultaneously").
} 
particular constitutional provision must be textualist, but the constructionwhich kicks in only when the text runs out—can, and perhaps should, be structuralist.

Professors Barnett and Bernick view their theory of construction as compelled by a commitment to originalism, but one that represents a commitment to the "spirit" or "original functions" of the text, rather than just the original meaning of the text. ${ }^{169}$ That is to say, the Framers' functional "intentions," rather than the objective public meaning of their words, guide the task of construction. ${ }^{170}$ After all, as Professor Solum has noted, no single theory of construction is compelled by the original meaning of the text; construction generally comes into play only when the original meaning is underdeterminate. ${ }^{171}$ As such, Professors Barnett and Bernick's theory requires judges to base their constitutional doctrine on more than just the original meaning of the text, contra the prevailing rhetoric of the new originalism. ${ }^{172}$

Structural arguments can be repurposed as constitutional constructions only if courts and theorists are willing and able to present them as means of determining the legal effect of particular constitutional provisions. However, that is not how the Supreme Court tends to deploy structural arguments. As noted above, the Court relies on structural arguments to find principles that are allegedly implicit in the constitutional design as a whole, rather than to give effect to particular ambiguous constitutional provisions. ${ }^{173}$

In addition, before they can justify the structural canon in these terms, originalists have to be willing to concede the existence of a substantial construction zone that persists even in cases involving federalism and separation of powers, not just individual rights cases. But this is something that many of them steadfastly refuse to do. ${ }^{174}$ A large construction zone means that there is a wide range of cases in which the original meaning is indeterminate. That, in turn, means that the original public meaning is not particularly constraining on judges.

\footnotetext{
169 See Barnett \& Bernick, supra note 164 , at 5.

170 See id.

171 See Solum, supra note 56, at 523.

172 See supra Introduction \& Part I.

173 See supra Part II.

174 See Solum, supra note 56, at 502-03 (detailing the arguments of new originalists who refuse to acknowledge the construction zone); $i d$. at 530 (arguing that even those new originalists who acknowledge the construction zone believe that "most of the provisions of the Constitution are structural and have clear original meanings: the detailed plan for the national government including the various rules constituting the Congress, presidency, and the judicial branch have discernable original meanings and much of that plan is substantially determinate").
} 
I have long pressed that view. ${ }^{175}$ But it has not swayed very many originalists, most of whom remain passionately wedded to the belief that the new originalism is the best antidote to judicial activism. ${ }^{176}$

\section{E. Transcending the Conflict: Accepting an Unwritten Constitution}

So, then it comes to this. Perhaps the conflict cannot be avoided. ${ }^{177}$ Perhaps structural reasoning cannot be reconciled with public meaning originalism, at least not in a way that most originalists will accept. If so, then originalists who want to continue to embrace structural arguments are going to have to relax their exclusive focus on the original meaning of the text as the source of all constitutional law.

An unblinking emphasis on the text is not, after all, inherently essential to the originalist enterprise. There are several ways that an originalist could accept, as binding constitutional law, structural rules that are not derived from the original meaning of the text.

\section{Returning to (or Moving Beyond) the Old Originalism}

It was much easier for originalists to embrace structural reasoning when their focus was on the original intentions and expectations of the Framers, rather than the original meaning of the text. ${ }^{178}$ Thus, for instance, Robert Bork once argued that "we would know" that

there is something special about speech ... even without a first amendment, for the entire structure of the Constitution creates a representative democracy, a form of government that would be meaningless without freedom to discuss

\footnotetext{
175 See Colby, supra note 10, at 755 n.253; cf. Solum, supra note 56, at 527-36 (noting that some critics have taken the construction zone as an indication that originalism is no longer theoretically or functionally distinct from nonoriginalism).

176 See Colby, supra note 10, at 749-51. Professors Barnett and Bernick's view is that, even if the original meaning is not in itself particularly constraining, originalism nonetheless constrains a great deal by requiring judges to respect the Constitution's spirit within the construction zone. But I am not convinced. Notions of structure are abstract enough that, even if a judge commits to be guided by them in the construction zone, she will still have tremendous leeway to reach various results. See infra note 213 and accompanying text.

177 This is John Manning's view. See supra Section III.B.

178 See, e.g., Raoul Berger, Federalism: The Founders' Design (1987); Manning, Generality, supra note 11, at 2005 (noting that the new federalism structural cases are grounded in "some version of original understanding or intent"); id. at 2025 (explaining that the Court's methodology involves "inferring from multiple clauses a general purpose of adopting a federal system and then treating that general purpose of federalism as a warrant to enforce the founders' uncodified expectations about limits on federal power"); $c f$. Thomas C. Grey, Do We Have an Unwritten Constitution?, 27 STAN. L. REV. 703, 716 (1975) (" $[\mathrm{I}] \mathrm{t}$ was generally recognized that written constitutions could not completely codify the higher law. Thus in the framing of the original American constitutions it was widely accepted that there remained unwritten but still binding principles of higher law.").
} 
government and its policies. Freedom for political speech could and should be inferred even if there were no first amendment. ${ }^{179}$

There is, of course, a great deal of historical evidence supporting the notion that the Framers also intended both federalism and separation of powers to be defining characteristics of the constitutional edifice. That notion pervades the Federalist Papers, for instance. ${ }^{180}$

The fact that the Framers did not explicitly encode those intentions and expectations into the text as freestanding limitations on governmental power poses a serious problem for public meaning originalism, but less of one for a version of originalism that treats those intentions as themselves binding. For the old originalism, the discussion of abstract structure in The Federalist is a compelling source of constitutional meaning. ${ }^{181}$ Indeed, The Federalist plays the starring role in the Court's new structuralist oeuvre. ${ }^{182}$

I say that the lack of explicit text poses "less of" a problem for the old originalism, rather than "no" problem at all, because even the old originalism placed substantial emphasis on the text. ${ }^{183}$ Professor Raoul Berger, for instance, explained that "original intent" was "shorthand for the meaning attached by the Framers to the words they employed in the Constitution and its Amendments." 184 Indeed, Professor Solum's ecumenical definition of originalism - which he understands to cover all forms of originalism, including original intent-maintains an exclusive focus on the text. ${ }^{185}$ And Professor Solum understands "Original Intentions Originalism" to consist of

179 Robert H. Bork, Neutral Principles and Some First Amendment Problems, 47 IND. L.J. 1, 23 (1971).

180 See, e.g., The Federalist No. 51 (James Madison)

181 See Gregory E. Maggs, A Concise Guide to the Federalist Papers as a Source of the Original Meaning of the United States Constitution, 87 B.U. L. REV. 801, 820-21 (2007); Jamal Greene, The Case for Original Intent, 80 GEO. WASH. L. REv. 1683, 1685 (2012) (noting that "The Federalist [is] one of the two main sources of the intentions of the Constitution's drafters"); Krista M. Pikus, When Congress Is Away the President Shall Not Play: Justice Scalia's Concurrence in NLRB v. Noel Canning, 114 Mich. L. ReV. FirST ImPressions 41, 47 (2015) ("While the Federalist Papers may be a persuasive source for the old-originalism method, it is less convincing for those who subscribe to the new-originalism approach.").

182 See 2016 National Lawyers Convention, supra note 86, at 59 (remarks of Judge William H. Pryor) (noting that Justice Scalia's "opinions on the structural issues of separation of powers and federalism often cited The Federalist Papers"); Greene, supra note 181, 1689-1702 (explaining that the Court cites The Federalist as evidence of original intent, not original meaning).

183 See Smith \& Tuttle, supra note 43, at 712 n.85 ("Even original-intent originalists such as Raoul Berger and Edwin Meese - whose approach generally sounded less 'textualist' than the approach of more recent, original-public-meaning originalists - regularly focused their inquiry on the constitutional text.").

184 BERGER, supra note 38, at 402.

185 See supra text accompanying note 57. 
the belief that "the original meaning of the constitutional text is the meaning that the framers intended to convey." 186

To embrace pure structural argument on intentionalist grounds, then, originalists would need to adopt a form of originalism that is even more reliant on the Framers' intentions and expectations, and even less reliant on the text, than the old originalism was. That prospect seems highly unlikely and not at all palatable to most originalists. The move from original intent to original meaning was an essential stride in shoring up many perceived weaknesses in originalist theory. ${ }^{187}$ Originalists are not about to beat a full retreat from Justice Scalia's successful "campaign to change the label from the Doctrine of Original Intent to the Doctrine of Original Meaning" 188 shortly after the death of its leader. Doing so would only resurrect the problems with the old originalism that prompted the campaign in the first place. Indeed, by drifting even further from the text, such an approach would only exacerbate those problems. ${ }^{189}$

\section{Adopting Text-and-Structure Originalism}

In the Introduction to this Essay, I noted Professor Ramsey's conclusion that Justice Scalia's brand of originalism was one in which judges should strike down laws that violate either the original meaning of the constitutional text or the original understanding of the constitutional structure. ${ }^{190}$ Originalists who seek to preserve structural argument could openly follow suit: continuing to champion the primacy of the original meaning of the text in constitutional law but not the exclusivity of the original meaning of the text. That move would allow for penumbral structural reasoning. ${ }^{191}$ Such reasoning is not truly dictated by the text, but it can be implied from the structure of the system established by the text, as explicated in the historical

\footnotetext{
${ }^{186}$ Lawrence B. Solum, Triangulating Public Meaning: Corpus Linguistics, Immersion, and the Constitutional Record, 2017 B.Y.U. L. REV. 1621, 1627.

187 See Colby, supra note 10, at 736-44.

188 Scalia, supra note 40, at 106.

189 See Young, supra note 31, at 1640 (observing that "focusing on the original understanding of structure rather than text would seem to exacerbate" the problems of the old originalism). To be sure, there are still some originalists who focus on original intent - and they offer sophisticated and thoughtful theories. See, e.g., Richard S. Kay, Original Intention and Public Meaning in Constitutional Interpretation, 103 Nw. U. L. REv. 703 (2009). But the vast majority of originalists have abandoned those views. See Colby, supra note 10, at 748-49. And, in any event, today's intentionalists maintain a focus on the intended meaning of the text, not abstract structural intentions. See Kay, supra, at 709 ( "It will be useful to clarify the definition of original intended meaning. I mean by that term the meaning that textual language had for the relevant enactors when they approved the text in question." (footnote omitted)).

190 See supra notes 33-34 and accompanying text.

191 See supra Section III.A.
} 
sources. ${ }^{192}$ Those structural rules could still be said to derive from the original understanding of the Framers and, indirectly, the original meaning of the Constitution as a whole. ${ }^{193}$

Professor Richard Primus has distinguished between the "'big-C' approach" to constitutional law, so called "because of the essential role that it reserves for the written Constitution - the proper noun, with a capital "C" - and the "'small-c' approach," which "draws on an older and more generic meaning of the noun "constitution." 194 The small-c approach allows for the possibility that some "rules not appearing in the text are nevertheless constitutional because they are important to the structure of government or because they reflect fundamental American values." 195

Justice Scalia's "text-and-structure originalism" essentially accepts a limited, small-c constitution. And Justice Scalia was not alone among originalists in doing so. Professor Akhil Amar, for instance, entitled his 2012 book America's Unwritten Constitution. ${ }^{196}$ As others have pointed out, Amar's book title is somewhat misleading, as most of the book actually endeavors to identify firm textual grounding for constitutional rules that might at first glance appear to be freestanding - often through the use of interpretive holism or creative textual hooks. ${ }^{197}$ Still, Amar does at times

192 Structural arguments need not be originalist in nature, but they can be. See Young, supra note 31, at 1639 ("Justice Kennedy diverges from Professor Black by emphasizing the historical understanding of the Constitution's structure rather than its present-day imperatives. The Court's method in Alden thus stands in the same relation to constitutional structure as an original meaning approach does to constitutional text.").

193 Professor Solum has previously opined that originalism does not necessarily rule out freestanding extratextual fundamental law, so long as that law does not directly contradict the public meaning of the text. On this view, a weak version of the "constraint principle" that requires only that constitutional doctrine not contradict the original meaning of the text is sufficient to qualify as originalist. See Solum, supra note 1, at 1966-67. I read Solum's most recent work as somewhat less forgiving, suggesting that the bare minimum for originalism includes a requirement that all constitutional doctrine be "fairly traceable" to the original meaning of the text. See Lawrence B. Solum, The Constraint Principle: Original Meaning and Constitutional Practice 19-21 (Apr. 13, 2018) (unpublished manuscript) (available at https://ssrn.com/abstract=2940215 [https://perma.cc/JLC7-FPTW]). But perhaps penumbral structural rules would meet that test.

194 Primus, supra note 116, at 1082.

195 Id.

196 See AMAR, supra note 157, at xi.

197 See Curtis A. Bradley \& Neil S. Siegel, Constructed Constraint and the Constitutional Text, 64 Duke L.J. 1213, 1272 (2015) ("Notwithstanding its title, much of Amar's book presents sophisticated arguments designed to show that the constitutional text, properly read, supports various well-accepted features of constitutional law, including some features that have been thought to have little connection to the text."); Paulsen, supra note 62, at 1388; Stephen E. Sachs, The "Unwritten Constitution" and Unwritten Law, 2013 U. ILl. L. ReV. 1797, 1809; David A. Strauss, Book Review: Not Unwritten, After All?, 126 HARV. L. REV. 1532, 1533 (2013) ("[D]espite the book's title, the star of the show is, in fact, the written Constitution. Many principles that one might think are unwritten turn out - when Amar is 
seem to endorse genuinely structural arguments that "read between the lines of the Constitution - to see what principles are implicit in the document, read as a whole, even if these principles are nowhere explicitly stated in any specific clause." 198 At times, his "basic constitutional argument is more structural than textual, sounding in both separation of powers and federalism." 199

Other originalists could follow suit. But I strongly suspect that most would be reluctant to do so openly. ${ }^{200}$ Professor Paulsen began his review of Professor Amar's book with an emphatic declaration that would likely appeal to most new originalists: "No, no, no! America has no 'unwritten constitution'! Ours is a system of written constitutionalism. There are only sound conclusions and inferences-or unsound ones-from the text itself." ${ }^{201}$ To drive the point home, Professor Paulsen later reiterated that "there is no such thing as 'America's Unwritten Constitution.' It is a misnomer, a hoax, a charade, a deception, a farce, a snare, a delusion, a lawyer's trick, a pickpocket's sleight of hand, a canard, to say that there is." ${ }^{202}$ Most modern originalists, steeped in the rhetoric and reasoning laid out in Part I of this Essay, are likely to see things Paulsen's way.

In the face of this heated opposition, the text-and-structure originalist would insist that the structural rules are implicit in the document or in the system of government set up by the document. Even if they cannot be squarely derived from the original meaning of the text, ${ }^{203}$ they nonetheless follow logically from the nature of the government that was set up by the text (as interpreted according to its original meaning). And they have constitutional status for the same reasons that the text does: because they follow from the structure set up by the ratified text (as understood in its

done with them - to be in the written Constitution itself, once you read the written Constitution the right way.").

198 AMAR, supra note 157, at xv; see id. at 20 (making "structural deductions from the constitutional system viewed holistically"); $i d$. at 30 ("Marshall treated the issue of state taxation of a federal agency as governed not so much by the decisive words of a single clause as by the deeper principles animating the document as a whole."); id. ("Marshall insisted on reading between the lines to vindicate the document's spirit, rather than focusing solely on its letter."); id. at 29 (arguing that the "free-expression core of [the First] amendment was itself merely declaratory — making textually plain what was otherwise strongly implicit" in "the Constitution as a "whole instrument"- the "entire Constitution's basic structure"; "[f]rom day one, the Constitution prohibited certain kinds of federal censorship even though the underlying prohibition could be said to be purely implicit").

199 Akhil Reed Amar, On Prosecuting Presidents, 27 Hofstra L. ReV. 671, 673 (1999).

200 See Solum, supra note 1, at 1967 ("Some originalists may believe that the spirit of originalism is fundamentally inconsistent with the notion of freestanding extratextual fundamental law, and hence freestanding extratextual fundamental law should not be called 'originalist.'”).

201 Paulsen, supra note 62, at 1385.

202 Id. at 1387.

203 See supra Section III.A. 
historical context), they too can be thought of as part of the original, fixed, and knowable higher law (thus consistent with the rule of law) that was agreed upon by the people (thus democratically legitimate).

However, accepting this argument would necessitate openly backing away from the fanatical insistence that only the text is law-and the holierthan-thou rhetoric that tends to accompany it. ${ }^{204}$ And Professor Manning has offered powerful reasons why an originalist should not feel comfortable doing so-why the basic assumptions that underlie this move should be viewed by originalists as unsound. Drawing upon insights from the textualist movement in statutory interpretation, which most new originalists endorse, ${ }^{205}$ Professor Manning argues that "the content of the original Constitution, as well as the circumstances surrounding its adoption, confirm the problematic nature of the Court's abstracting a freestanding federalism [or separation of powers] norm from the constitutional structure as a whole." 206 " $[\mathrm{N}]$ o less than is true in the case of modern statutes, the original Constitution in fact reflects the end result of hard-fought compromise." 207 The Constitution defines "federalism" and "separation of powers" "only through its adoption of a number of particular measures that collectively reflect the background aim of establishing" a system of government that divides power vertically and horizontally. ${ }^{208}$ "Treating that background aim as a freestanding legal norm devalues the choice to bargain over, settle upon, and present to the ratifying conventions a cluster of relatively, even if imperfectly, specified means to achieve that aim." ${ }^{209}$ In addition, enforcing federalism or separation of powers "in the abstract runs afoul of the notion that enacted laws have multiple, imperfectly aligned purposes." 210 The Constitution seeks to embrace federalism and separation of powers, but it also seeks to provide a functional and effective national government, "and decisions about where one impulse begins and the other ends cannot be made in the abstract, without reference to the particular clauses that purport to draw the lines." 211 In other words, it is "difficult not to conclude that the founders came to terms upon a number of particular provisions prescribing varied means of allocating governmental power, rather than adopting federalism [and separation of powers] in the abstract." 212

\footnotetext{
204 See supra Introduction \& Part I.

205 See, e.g., Scalia, supra note 2, at 23-25, 37-40.

206 Manning, Generality, supra note 11, at 2040.

207 Id.

208 Id.

209 Id.

${ }^{210} \mathrm{Id}$.

$211 \mathrm{Id}$.

${ }^{212} I d$. at 2052.
} 
What is more, expanding originalism beyond the text, to include structure, necessarily brings with it substantial judicial flexibility of the type that originalism generally seeks (and claims) to avoid. As Professor Calabresi explains, abstract structural reasoning "runs the risk of imagining the structure that one wants to see. Structuralism ... raises the level of generality of the constitutional text to too high a level,... thus making unavoidable the importation of one's own personal policy views." 213

Indeed, a commitment to both text and structure, rather than the text alone, starts to look like Professor Larry Tribe's jurisprudence, which eschews free-form constitutionalism, but places

great emphasis upon text and structure, both the structure within the text- the pattern and interplay in the language of the Constitution itself and its provisions - and the structure (or architecture) outside the text - the pattern and interplay in the governmental edifice that the Constitution describes and creates, and in the institutions and practices it propels. ${ }^{214}$

Tribe's view is that "structural forms of inference are of course appropriate when one is addressing matters of governmental architecture, such as the relationship between the states and the national government, or the relationships among the three national branches," even though they are "untethered to text." 215 Yet Tribe has always been something of a bête noire of originalists. ${ }^{216}$

213 Steven G. Calabresi, The Vesting Clauses as Power Grants, 88 Nw. U. L. REV. 1377, 1401-02 (1994); see also Dorf, supra note 20, at 838; Green, supra note 106, at 686 (noting that "structural arguments' abstraction also yields interpretive flexibility"); Manning, Foreword, supra note 11, at 4-5 ("Because those cases turn on abstract and often conflicting structural policies, their outcomes almost always involve large interpretive discretion and fall within a range in which reasonable people can easily disagree. By exercising independent judgment in those cases, the Court gives itself, rather than Congress, the final say about how to implement federal power."); Michael Stokes Paulsen, Abrogating Stare Decisis by Statute: May Congress Remove the Precedential Effect of Roe and Casey?, 109 YALE L.J. 1535, 1582 (2000) ("It is a classic lawyer's trick - and an especially easy trick to play with separation-of-powers structural arguments - to take a text, series of texts, or asserted relationship between texts, discern some 'principle' within it (formulated at a sufficiently high level of generality), and then read that principle back into the Constitution."); Paulsen, supra note 62, at 1388 ("Amar's unwritten constitution permits almost any ingenious, overclever outcome that a judge might care to reach."); Young, supra note 31, at $1636-37$ ("Black's ability time and again to justify morally appealing results on structural grounds might, after a while, give rise to the suspicion that a sufficiently skillful structuralist can justify any result he pleases.").

${ }^{214}$ Laurence H. Tribe, Taking Text and Structure Seriously: Reflections on Free-Form Method in Constitutional Interpretation, 108 HARV. L. REV. 1221, 1236 (1995).

215 TriBE, supra note 123, $\S 1-13$, at 45 ; see also LAURENCE H. TRIBE, THE Invisible CONSTITUTION 170-71 (2008) (asserting "the unavoidable existence of ... the Constitution's allimportant set of 'invisible' structures and principles").

216 See Douglas H. Ginsburg, Originalism and Economic Analysis: Two Case Studies of Consistency and Coherence in Supreme Court Decision Making, 33 HARV. J.L. \& PUB. POL'y 217, 227 (2010) 
Tribe's work serves as a cautionary tale for many originalists. He has repeatedly insisted that there is no principled basis for simultaneously rejecting unenumerated rights on the ground that they cannot be located in the constitutional text, yet also employing penumbral or structural reasoning to discover implicit federalism or separation of powers principles. ${ }^{217}$

Text-and-structure originalism would need either to agree or to articulate a compelling reason why Tribe is wrong.

\section{Moving from Original Meaning to Original Law}

Finally, originalists could overcome the conflict between public meaning textualism and structural argument by reorienting their theory away from the text. This is the promising path forward offered by Professor Stephen Sachs, a leader among the new generation of originalist thinkers, who has opined that, contrary to the prevailing thrust of originalist theory today, "[o]riginalism is not about the text." 218

Professor Sachs explains that we can imagine a society that does not have written law at all, and yet has a legitimately originalist legal system that defines the content of its fundamental law by reference to binding oral decisions made in the past. ${ }^{219}$ "If having a text isn't fundamental to originalism," Professor Sachs argues, "then originalism isn't fundamentally about the meaning of texts." 220

Professor Sachs is part of a growing cohort of originalist scholars who advocate "shifting [the] focus" of the originalist inquiry again: this time "from original meaning to our original law: the law of the United States as it stood at the Founding, and as it's been lawfully amended since." 221 According to these thinkers, what makes a theory originalist is not its commitment to the text, but rather its commitment to the notion that "the content of American constitutional law ... properly rest[s] on its origins-

\footnotetext{
(discussing "Laurence Tribe of Harvard Law School-whom no one has ever accused of being an originalist").

217 See TRIBE, supra note 123, $\S 1.13$, at 46 ("It would be utterly incoherent to suggest that our Constitution's rules and principles for dividing up power and authority within the national government, or between it and the states, are about structure and therefore cannot be understood through a focus on text alone while maintaining that our Constitution's rules and principles for dividing up power and authority between government and individuals and private groups, although they too are obviously about structure, can be fathomed through suitably cadenced mediations upon the text without attention to more global, structural features of the situation.").

218 Sachs, supra note 29, at 157.

219 See id. at 159-62.

220 Id. at 157.

221 Id. at 158; see also Baude, supra note 43, at 2351; Jeffrey A. Pojanowski \& Kevin C. Walsh, Enduring Originalism, 105 GEO. L.J. 97, 99 (2016); Stephen E. Sachs, Originalism as a Theory of Legal Change, 38 HARV. J.L. \& PUB. POL'Y 817, 821 (2015).
} 
on features of our legal Founding that remain legally operative today." 222 "[P]reserving legal propositions, as opposed to the meanings of words, is often what originalists care about most." ${ }^{223}$ And many of those propositions were not encoded in the constitutional text; "important parts of our original law were unwritten." 224

This shift would seem to allow an originalist to endorse some of the Court's structural decisions without blushing. For instance, "the Eleventh Amendment really doesn't say everything the Court said in Alden v. Maine. Yet Alden might still be right, and on wholly originalist grounds. If originalism draws on the Founders' legal rules as well as their language, then no embarrassment is necessary." 225

It is not clear, though, how much of the structuralist canon this move would save. An "original law" originalist is not just trying to figure out what the law was at the time of the Framing. She is trying to figure out what the constitutional law was at that time. Why would an originalist draw upon and continue to apply particular Framing-era legal rules to invalidate current legislation and governmental actions unless those rules are of constitutional dimension? ${ }^{226}$ Professor Sachs's view is that a rule of background law from the Founding Era is properly applied to invalidate government actions today only if that rule is properly characterized as a "constitutional backdrop," a rule of original law that was not itself codified in the text of the Constitution, yet is protected by some other provision of the text of the Constitution from the ordinary means of legal change. ${ }^{227}$

Perhaps some of the Court's structural decisions could be defended in this manner. ${ }^{228}$ However, it will take some work to identify which ones and to explain which textual provisions, properly understood in their historical context, insulate those unenumerated structural principles from change by ordinary law. It is not obvious to me that most of the Court's structural cases - especially those grounded in abstract notions of federalism and separation of powers distilled by generalizing up from specific inapplicable

\footnotetext{
222 Sachs, supra note 29, at 158.

223 Id. at 168; see also id. at 161 (“[O]riginalists aren't merely figuring out what certain writings communicated at some point in the past (such as by consulting a dictionary or a linguistic corpus); they're using those writings to determine what the law was back then, with all its various exceptions, augmentations, and epicycles included.").

224 Id. at 166.

225 Id. (footnotes omitted). Those legal rules would include common law principles of jurisdiction. See Sachs, supra note 155, at 1869-72.

${ }^{226}$ Cf. Sachs, supra note 197, at 1845 (noting that unwritten law generally does not have constitutional status).

227 See Sachs, supra note 155, at 1816, 1874-75.

228 See, e.g., Baude, supra note 32, at 2 (defending sovereign immunity as a constitutional backdrop).
} 
clauses and drawing upon the big-picture rhetoric of the Federalist Papers and other historical sources - could be recast in backdrop terms.

And even if that work can be done, for public meaning originalists to follow this path, they will have to get past their obsession with the text, which has been central to the originalist enterprise in recent years.

\section{CONCLUSION}

There is an obvious conflict between originalism as it is generally described by those who endorse it - as a form of constitutional textualismand the many cases in the conservative constitutional canon that rely on abstract, untethered notions of structure in lieu of the original meaning of any particular provision of the Constitution. This Essay has endeavored to demonstrate that conflict, and to lay out the possible ways in which originalists might seek to resolve it. To summarize in a nutshell, I do not see any easy answers - at least none that are likely to appeal to most originalists. 